\title{
Evaluation of General
}

Mills' and Kellogg's

\section{GHG Emissions}

\section{Targets and Plans}

Independent Assessment conducted by Winston Eco-Strategies for Oxfam's Behind the Brands Initiative 


\section{TABLE OF CONTENTS}

$\begin{array}{ll}\text { TABLE OF CONTENTS } & 1\end{array}$

I. EXECUTIVE SUMMARY FINDINGS 2

II. INTRODUCTION \& BACKGROUND

III. FRAMEWORK FOR ASSESSMENT

IV. ASSESSMENT OF GENERAL MILLS' GHG TARGETS AND PLANS 10

V. ASSESSMENT OF KELLOGG'S GHG TARGETS AND PLANS 15

VI. RECOMMENDATIONS, BEST PRACTICES FOR FOOD COMPANIES SETTING GHG TARGETS 20

$\begin{array}{lr}\text { VII. CONCLUSIONS } & 24\end{array}$

$\begin{array}{lr}\text { VIII. APPENDICES } & 25\end{array}$

Disclaimer:

The research for this report was supported by Oxfam to contribute to the Behind the Brands initiative, and to add to the public debate on development and climate change policy and practice. This report does not necessarily reflect Oxfam policy positions and the views expressed are those of the author 


\section{EXECUTIVE SUMMARY FINDINGS}

Winston Eco-Strategies, in support of Oxfam's Behind the Brands initiative, developed a framework of questions and metrics to assess General Mills' and Kellogg's recently announced greenhouse gas (GHG) reduction targets. The goal of the project is to assess whether (a) the targets for their own operations and for upstream agricultural suppliers are in keeping with science-based target methodologies, and (b) the plans to get there are robust enough to make success likely.

WES conducted this assessment using information and data that was publicly available, including company sustainability reports, websites, policy statements, and news articles. The report below explains the scoring methodology more fully. The following are the summary results of the assessment for the two companies.

\section{General Mills:}

Overall assessment: Meets the current requirements for science-based target setting and having sufficient plans to achieve those targets, with the exception of one category, the "Strength of data behind the targets" where the publicly available information was not sufficient to determine the source and strength of some aspects of the data.

\begin{tabular}{|c|c|c|}
\hline Category \# & Category & Assessment \\
\hline 1.1 & $\begin{array}{l}\text { Base information on the target and inclusion of scope } 3 \\
\text { (primarily agricultural emissions) }\end{array}$ & Meets \\
\hline 1.2 & Strength of data behind targets & Fails/Unknown \\
\hline 1.3 & $\begin{array}{l}\text { Strength/quality of target on agricultural emissions } \\
\text { specifically }\end{array}$ & Meets* \\
\hline 1.4 & $\begin{array}{l}\text { Consistency with } 2 \mathrm{C} \text { science-based methodology and } \\
\text { thresholds }\end{array}$ & Meets** \\
\hline 1.5 & Consistency with best practice & Exceeds \\
\hline 2.1 & Governance/Accountability & Exceeds \\
\hline 2.2 & Supplier engagement plans for GHG reductions & Exceeds \\
\hline 2.3 & Measurement and Metrics & Meets \\
\hline 2.4 & Interim goals and target adjustments/flexibility & Meets \\
\hline 2.5 & Transparency and communications & Meets \\
\hline
\end{tabular}




\section{Kellogg}

Overall assessment: Meets the current requirements for science-based target setting and having sufficient plans to achieve those targets.

\begin{tabular}{|c|c|c|}
\hline Category \# & Category & Assessment \\
\hline 1.1 & $\begin{array}{l}\text { Base information on the target and inclusion of scope } 3 \\
\text { (primarily agricultural emissions) }\end{array}$ & Meets \\
\hline 1.2 & Strength of data behind targets & Meets \\
\hline 1.3 & $\begin{array}{l}\text { Strength/quality of target on agricultural emissions } \\
\text { specifically }\end{array}$ & Meets* \\
\hline 1.4 & $\begin{array}{l}\text { Consistency with } 2 \mathrm{C} \text { science-based methodology and } \\
\text { thresholds }\end{array}$ & Meets* \\
\hline 1.5 & Consistency with best practice & Exceeds \\
\hline 2.1 & Governance/Accountability & Meets \\
\hline 2.2 & Supplier engagement plans for GHG reductions & Meets \\
\hline 2.3 & Measurement and Metrics & Meets \\
\hline 2.4 & Interim goals and target adjustments/flexibility & Exceeds \\
\hline 2.5 & Transparency and communications & Meets \\
\hline
\end{tabular}

*For both companies, their work to reduce supply chain emissions is focused on key crops and suppliers, which do make up a large percentage of the supply chain. But the public statements are not entirely clear on whether the GHG targets as stated apply to all suppliers or only those producing the priority ingredients. General Mills' target can more easily be read as applying to all, while Kellogg's target is focused on $75-80 \%$ of the suppliers. Over time, the target would need to apply to the full value chain to remain a science-based target.

**While both companies clearly exceed industry peers in setting ambitious climate mitigation targets and goals that apply to scope 3 supply chain emissions, and have used currently available methods and tools for setting science-based targets (SBTs), there are some caveats that apply. COP 21 adopted a long term mitigation goal "to pursue efforts to limit the temperature increase to $1.5^{\circ} \mathrm{C}$ above pre-industrial levels" which would entail more aggressive cuts in emissions, and current tools for setting SBTs do not appropriately capture decarbonization pathways for agriculture. 


\section{INTRODUCTION \& BACKGROUND}

The food and agriculture sector (Food \& $\mathrm{Ag}$ ) has a significant role and stake in climate change. Extreme weather is threatening food supply chains around the world. The sector is also a large contributor to climate change, responsible for up to $25 \%$ of total global emissions.

As in most sectors, the largest companies in Food \& Ag have responded to the challenge, in part, by setting targets to reduce emissions, mostly from their own operations (so-called scope 1 and 2 emissions).

Oxfam's Behind the Brands initiative has focused attention on "The Big 10" food and beverage companies, encouraging these companies to take on two emerging best practices:

(1) Set their goals based on how fast science tells us we need to cut emissions (sciencebased targets, or SBTs) and,

(2) Set goals for their supply chains as well, which is critical in Food \& Ag since upstream (or scope 3) emissions are the majority of total emissions - equal to, according to Oxfam, the carbon emissions of around 40 coal-fired power stations each year.

In the summer of 2014, both General Mills and Kellogg released climate change plans and goals that cover the period up until 2020. Both also committed to set supply chain targets that address agricultural emissions as well. In the fall of 2015, the companies established new targets for GHG emissions that covered scopes 1, 2, and 3 emissions. In addition, in April 2016, General Mills released its latest Global Responsibility Report which extended some of its targets.

This report is focused on the following new goals and the companies' respective plans to reach the new targets:

- General Mills: "A 28 percent absolute reduction in greenhouse gas emissions by 2025" across the entire value chain and, as of the April 2016 Global Responsibility Report, a new 2050 target to "reduce absolute GHG emissions across our full value chain by 41$72 \%$ (compared to 2010) to achieve sustainable levels in line with scientific consensus."

- Kellogg: "Cut GHG emissions by 65 percent across its own operations, known as Scope 1 and 2, and, for the first time work with suppliers, known as Scope 3, to help reduce their emissions by 50 percent by 2050."

Oxfam engaged Winston Eco-Strategies, LLC (WES) to provide an evaluation of these targets. In conjunction with Oxfam, WES developed a framework of questions and metrics to gauge the robustness of General Mills' and Kellogg's greenhouse gas (GHG) targets and plans.

The purpose of this process is to assess whether...

(a) The target GHG reductions for the companies and their supply chains are in line with credible science-based target methodologies and

(b) The companies' action plans reflect enough organizational, informational, and financial commitment and management to both measure progress against the targets and also make the achievement of those goals likely.

WES conducted this assessment using information and data that was publicly available, including company sustainability reports, websites, policy statements, and news articles. 


\section{FRAMEWORK FOR ASSESSMENT}

\section{Framework elements}

In conjunction with Oxfam, Winston Eco-Strategies developed a framework for assessing science based targets and plans to achieve those targets. The framework consists of a two-part assessment, which reviews the target itself (part 1) and the plans to reach the target (part 2).

Each part has 5 categories which each have a number of questions, for a total of 33 questions. The overall purpose of the assessment is to gauge whether (a) the goals are in keeping with the established science-based targets approaches (such as WRI and CDP's methodology) and (b) the plan to get there is robust enough to make achievement likely.

\section{Scoring Rubrics}

For each metric, we employ one of two assessment rubrics. Some metrics are binary and just measure a simple yes/no (e.g., is the target set for absolute emissions?). For most of the more challenging questions, the rubric is what we're calling $E / M / F$, which means the following.

- $E=$ Exceeds what's necessary for achieving science based targets and plans

- $\mathrm{M}=$ Meets requirements necessary for achieving science based targets and plans

- $\mathrm{F}=$ Fails to meet requirements necessary for achieving science based targets and plans

Based on the scores received across all of the individual metrics per category, each of the ten categories of the framework receives a summary score of $E / M / F$ as well.

- $E=A$ rating of Yes or $E$ for most indicators within that category, and with a minimum of a rating of Yes or $M$ for all indicators within that category

- $M=A$ rating of Yes or $M$ for most indicators within that category

- $F=A$ rating of No or $F$ (or unknown) for most indicators within that category

Below is the full framework used to assess General Mills' and Kellogg's GHG targets. 


\begin{tabular}{|c|c|c|c|}
\hline $\begin{array}{l}\text { Category/ } \\
\text { Questions }\end{array}$ & Category & Data Format & Assessment Rubric \\
\hline 1.1 & $\begin{array}{l}\text { Base information on the target and inclusion } \\
\text { of scope } 3 \text { (primarily agricultural emissions) }\end{array}$ & & $\begin{array}{l}\mathrm{E} / \mathrm{M} / \mathrm{F} \\
\text { (Category assessment) }\end{array}$ \\
\hline 1 & What is the target GHG reduction? & $\%$ & Yes/no \\
\hline 2 & $\begin{array}{l}\text { Is the target for absolute emissions (vs. } \\
\text { relative/intensity)? }\end{array}$ & Yes/no & Yes/no \\
\hline 3 & $\begin{array}{l}\text { What is the timeline of the target? Baseline? } \\
\text { Starting when and by when? }\end{array}$ & Years & Yes/no \\
\hline 4 & $\begin{array}{l}\text { What parts of value chain are included in the } \\
\text { target? Are scope } 3 \text { and/or agricultural } \\
\text { emissions included? }\end{array}$ & $\begin{array}{l}\text { Details; } \\
\text { Yes/No }\end{array}$ & Yes/no \\
\hline 5 & $\begin{array}{l}\text { How is the target divided amongst value } \\
\text { chain parts (all the same target or variable)? }\end{array}$ & Details & $\mathrm{E} / \mathrm{M} / \mathrm{F}$ \\
\hline 1.2 & Strength of data behind targets & & $\begin{array}{l}\text { E/M/F } \\
\text { (Category assessment) }\end{array}$ \\
\hline 6 & $\begin{array}{l}\text { Does the company have GHG emission data } \\
\text { with percentages broken down by scope } \\
\text { and/or value chain stage (e.g. } 70 \% \text { supply } \\
\text { chain; } 25 \% \text { operations; } 5 \% \text { EOL) }\end{array}$ & $\begin{array}{l}\% \text { with } \\
\text { details }\end{array}$ & Yes/No \\
\hline 7 & $\begin{array}{l}\text { How is data on agricultural emissions } \\
\text { reported and analyzed ?(e.g., does the } \\
\text { company have data on agricultural emissions, } \\
\text { is the data aggregated or broken down by } \\
\text { ingredient/commodity or by category (dairy } \\
\text { vs. row crops)?) }\end{array}$ & $\begin{array}{l}\text { \% with } \\
\text { details }\end{array}$ & $\mathrm{E} / \mathrm{M} / \mathrm{F}$ \\
\hline 8 & $\begin{array}{l}\text { How are agricultural emissions data } \\
\text { calculated? (e.g., actual yield combined with } \\
\text { emissions estimated from academic studies } \\
\text { of specific crops)? }\end{array}$ & Details & $\mathrm{E} / \mathrm{M} / \mathrm{F}$ \\
\hline 9 & $\begin{array}{l}\text { What is the quality of company's data } \\
\text { including agricultural emissions (e.g., what is } \\
\text { baseline year of solid data for GHGs, is data } \\
\text { third party verified?) }\end{array}$ & Details & $\mathrm{E} / \mathrm{M} / \mathrm{F}$ \\
\hline 1.3 & $\begin{array}{l}\text { Strength/quality of target on agricultural } \\
\text { emissions specifically }\end{array}$ & & $\begin{array}{l}\mathrm{E} / \mathrm{M} / \mathrm{F} \\
\text { (Category assessment) }\end{array}$ \\
\hline 10 & $\begin{array}{l}\text { What \% of agricultural ingredients is included } \\
\text { in the target (By volume of ingredients? By } \\
\text { CO2e of agricultural emissions?) }\end{array}$ & $\%$ & $\mathrm{E} / \mathrm{M} / \mathrm{F}$ \\
\hline 11 & $\begin{array}{l}\text { 'What sources of agricultural emissions are } \\
\text { included in the target? (List: Deforestation } \\
\text { and other land use change b. livestock } \\
\text { emissions (both enteric fermentation and } \\
\text { manure management) c.rice production d. } \\
\text { nitrogen fertilizer application (both synthetic } \\
\text { and manure); e. peatland drainage; f. on farm }\end{array}$ & Details & $\mathrm{E} / \mathrm{M} / \mathrm{F}$ \\
\hline
\end{tabular}




\begin{tabular}{|c|c|c|c|}
\hline & $\begin{array}{l}\text { energy use, and g. upstream fertilizer } \\
\text { production, h. other as applicable) }\end{array}$ & & \\
\hline 12 & $\begin{array}{l}\text { How is food waste -- i.e., losses on-farm or } \\
\text { between farm and manufacturing -- } \\
\text { accounted for? (i.e., is all farm production } \\
\text { included or just emissions related to inputs } \\
\text { that are utilized) }\end{array}$ & Details & $\mathrm{E} / \mathrm{M} / \mathrm{F}$ \\
\hline 1.4 & $\begin{array}{l}\text { Consistency with } 2 \mathrm{C} \text { science-based } \\
\text { methodology and thresholds }\end{array}$ & & $\begin{array}{l}\mathrm{E} / \mathrm{M} / \mathrm{F} \\
\text { (Category assessment) }\end{array}$ \\
\hline 13 & $\begin{array}{l}\text { What was the target setting process and } \\
\text { what, if any, science based methodologies } \\
\text { were utilized? (e.g., does the target align with } \\
\text { carbon budget estimations from IPCC, was } \\
\text { the target derived through straight-line } \\
\text { reductions or sector-based methodologies } \\
\text { etc?) }\end{array}$ & Details & $\mathrm{E} / \mathrm{M} / \mathrm{F}$ \\
\hline 1.5 & Consistency with best practice & & $\begin{array}{l}\mathrm{E} / \mathrm{M} / \mathrm{F} \\
\text { (Category assessment) }\end{array}$ \\
\hline 14 & $\begin{array}{l}\text { How does the target compare to the most } \\
\text { aggressive SBTs from the Global Fortune } 500 \\
\text { or other best practice examples (e.g. goals on } \\
\text { renewable energy, waste reduction, } \\
\text { deforestation) }\end{array}$ & $\begin{array}{l}\text { NA - WES } \\
\text { analysis }\end{array}$ & $\mathrm{E} / \mathrm{M} / \mathrm{F}$ \\
\hline \multicolumn{4}{|c|}{ Part 2. Plan to Reach the Goals/Targets } \\
\hline $\begin{array}{l}\text { Category/ } \\
\text { Questions }\end{array}$ & Category & $\begin{array}{l}\text { Data } \\
\text { Format }\end{array}$ & Assessment Rubric \\
\hline 2.1 & Governance/Accountability & & $\begin{array}{l}\mathrm{E} / \mathrm{M} / \mathrm{F} \\
\text { (Category assessment) }\end{array}$ \\
\hline 15 & $\begin{array}{l}\text { Who in the organization is responsible for } \\
\text { meeting GHG targets? And for measuring, } \\
\text { estimating agric. emissions? }\end{array}$ & Details & $\mathrm{E} / \mathrm{M} / \mathrm{F}$ \\
\hline 16 & $\begin{array}{l}\text { Is there CEO or Board oversight on carbon } \\
\text { targets? }\end{array}$ & Yes/no & Yes/no \\
\hline 17 & $\begin{array}{l}\text { Are there incentives in place for company } \\
\text { managers, or for suppliers, to meet GHG } \\
\text { targets? }\end{array}$ & Details & $\mathrm{E} / \mathrm{M} / \mathrm{F}$ \\
\hline 2.2 & $\begin{array}{l}\text { Supplier engagement plans for GHG } \\
\text { reductions }\end{array}$ & & $\begin{array}{l}\mathrm{E} / \mathrm{M} / \mathrm{F} \\
\text { (Category assessment) }\end{array}$ \\
\hline 18 & $\begin{array}{l}\text { How will the company require suppliers to } \\
\text { measurably reduce agricultural emissions } \\
\text { (e.g., what mechanisms such as supplier } \\
\text { codes will be used)? }\end{array}$ & Details & $\mathrm{E} / \mathrm{M} / \mathrm{F}$ \\
\hline 19 & $\begin{array}{l}\text { How will the company assess pathways to } \\
\text { reductions and opportunities to embed new } \\
\text { sustainable agricultural practices and }\end{array}$ & Details & $\mathrm{E} / \mathrm{M} / \mathrm{F}$ \\
\hline
\end{tabular}




\begin{tabular}{|c|c|c|c|}
\hline & $\begin{array}{l}\text { techniques? What external experts or } \\
\text { partners, if any, will be consulted? }\end{array}$ & & \\
\hline 20 & $\begin{array}{l}\text { How will the company provide suppliers best } \\
\text { practices on key sustainable agricultural } \\
\text { techniques (e.g., no-tillage, cover crops, } \\
\text { rotation, nutrient management, manure } \\
\text { management)? }\end{array}$ & Details & $\mathrm{E} / \mathrm{M} / \mathrm{F}$ \\
\hline 21 & $\begin{array}{l}\text { Will the company aid suppliers on } \\
\text { implementing new technologies and } \\
\text { techniques directly (e.g., with human or } \\
\text { financial capital?) }\end{array}$ & Details & $\mathrm{E} / \mathrm{M} / \mathrm{F}$ \\
\hline 22 & $\begin{array}{l}\text { How will the progress of operational changes } \\
\text { in the supply chain be tracked? }\end{array}$ & Details & $\mathrm{E} / \mathrm{M} / \mathrm{F}$ \\
\hline 23 & $\begin{array}{l}\text { Does the company have policies and plans for } \\
\text { achieving zero deforestation across all high } \\
\text { forest risk commodities it sources? }\end{array}$ & Yes/No & Yes/No \\
\hline 24 & $\begin{array}{l}\text { Does the company have policies and plans for } \\
\text { sustainably sourcing of commodities with a } \\
\text { high environmental footprint that are } \\
\text { relevant for its supply chain? (e.g., } \\
\text { commodities such as cocoa, coffee or sugar)? }\end{array}$ & Yes/No & Yes/No \\
\hline 2.3 & Measurement and metrics & & $\begin{array}{l}\mathrm{E} / \mathrm{M} / \mathrm{F} \\
\text { (Category assessment) }\end{array}$ \\
\hline 25 & $\begin{array}{l}\text { What will the process be for regularly } \\
\text { measuring and reporting on GHGs in } \\
\text { operations, supply chain, and downstream } \\
\text { (scopes } 1,2,3 \text { )? What tools or models will be } \\
\text { used? }\end{array}$ & Details & $\mathrm{E} / \mathrm{M} / \mathrm{F}$ \\
\hline 26 & $\begin{array}{l}\text { Will supplier-level agricultural emissions be } \\
\text { tracked directly (vs. estimated from total } \\
\text { ingredient yields across all suppliers of a } \\
\text { given ingredient)? Will the company provide } \\
\text { tools/assistance to suppliers to track their } \\
\text { GHGs? }\end{array}$ & Details & $\mathrm{E} / \mathrm{M} / \mathrm{F}$ \\
\hline 27 & $\begin{array}{l}\text { What Is the process for assessing and } \\
\text { reporting data on carbon reductions, } \\
\text { particularly Scope } 3 \text { ? (e.g., is it certified by a } \\
\text { third-party for data legitimacy?) }\end{array}$ & Details & $\mathrm{E} / \mathrm{M} / \mathrm{F}$ \\
\hline
\end{tabular}




\begin{tabular}{|c|c|c|c|}
\hline 2.4 & $\begin{array}{l}\text { Interim goals and target } \\
\text { adjustments/flexibility }\end{array}$ & & $\begin{array}{l}\mathrm{E} / \mathrm{M} / \mathrm{F} \\
\text { (Category assessment) }\end{array}$ \\
\hline 28 & Are there targets in place for interim years? & Yes/no & Yes/no \\
\hline 29 & $\begin{array}{l}\text { What are the interim targets and for which } \\
\text { parts of the value chain? }\end{array}$ & Details & $\mathrm{E} / \mathrm{M} / \mathrm{F}$ \\
\hline 30 & $\begin{array}{l}\text { How will the company incorporate the } \\
\text { evolving science on climate change? }\end{array}$ & Details & $\mathrm{E} / \mathrm{M} / \mathrm{F}$ \\
\hline 31 & $\begin{array}{l}\text { Is there a process in place to re-set or re- } \\
\text { establish the goals before the target year if } \\
\text { necessary? }\end{array}$ & Details & $\mathrm{E} / \mathrm{M} / \mathrm{F}$ \\
\hline 2.5 & Transparency and communications & & $\begin{array}{l}\mathrm{E} / \mathrm{M} / \mathrm{F} \\
\text { (Category assessment) }\end{array}$ \\
\hline 32 & $\begin{array}{l}\text { Is the information on GHG reduction targets } \\
\text { and plans available publicly in a transparent } \\
\text { and accessible manner? }\end{array}$ & Details & $\mathrm{E} / \mathrm{M} / \mathrm{F}$ \\
\hline 33 & $\begin{array}{l}\text { How will updates on implementation } \\
\text { progress be shared? How frequently? }\end{array}$ & Details & $\mathrm{E} / \mathrm{M} / \mathrm{F}$ \\
\hline
\end{tabular}

\section{Inherent Constraints}

As this exercise is qualitative in nature, many elements along the $E / M / F$ spectrum reflect a judgment about what would be necessary to make reaching the goals more likely. Even if these processes and organizational structures are in place, the result - attaining a science-based level of reductions across the value chain - is not guaranteed.

An important caveat for this exercise: some of the areas reflect a desired state instead of the reality on the ground. In particular, in the area of measurement of agricultural emissions, the "state of the art" is currently to estimate total emissions for a crop based on actual yields multiplied by estimated emissions for that crop from academic studies of one particular site. That kind of estimate does not reflect differences in growing region or farming methods. In the future, to measure progress against reduction targets, companies may require much more accurate, farm-level data on an ongoing basis.

Finally, this process is utilizing today's science-based target-setting methodologies. But each iteration of the IPCC process has lowered the budget on global carbon - meaning, what is considered sufficient for science today is unlikely to be sufficient tomorrow. This is one of the reasons the framework includes questions 30 and 31. This reality of changing (and likely everstricter) guidelines on carbon has an important ramification for this process. An assessment that the goals are in line with science is not valid indefinitely and must be reassessed periodically. 


\section{ASSESSMENT OF GENERAL MILLS’ GHG TARGETS AND PLANS}

Below is a summary of the assessment at the category level. For a more detailed look at the assessment of each of the 33 questions, please see the spreadsheet included as Appendix B, which also includes information about where in the public documents WES sourced the data.

\section{Robustness of Target Setting}

\section{1: Base Information on the Target and Inclusion of Scope 3}

This sub-category includes five metrics or questions:

1. What is the target $\mathrm{GHG}$ reduction percentage?

2. Is the target based on absolute or intensity calculations?

3. What is the timeline of the target (baseline, due date)?

4. What parts of the value chain are included in the target?

5. How is the target divided amongst the value chain parts?

\section{Assessment: Meets}

Rationale: Category 1.1 primarily measures whether the goal is stated clearly and covers scope 3 (i.e., agricultural) emissions. All metrics included in the category received a "Meets" or "Yes" response. However, the answer to question \#5 on how the target is applied to the value chain is not clear from public documents, which include the $28 \%$ target for the full value chain and statements about collaborating with suppliers. But it's unclear if the $28 \%$ is expected for each of scopes 1, 2, and 3 specifically (i.e., in theory, the $28 \%$ could be broken up a number of ways, including a higher percentage for General Mills' own operations and lower for suppliers...or vice versa).

\section{2: Strength of data behind targets}

This subcategory consists of four questions or metrics:

6. Does the company have GHG emission data with percentages broken down by scope and/or value chains?

7. How is data on agricultural emissions reported and analyzed?

8. How are agricultural emissions data calculated?

9. What is the quality of company's data including agricultural emissions data

\section{Assessment: Fails/Unknown}

Rationale: From public information it is clear that General Mills has conducted field tests with tools to measure GHGs in a few different settings. But it's not explicitly stated how the company has measured or estimated total upstream agricultural emissions for all ingredients. Metrics 7, 8, and 9 cover this area. The company's CDP report discusses an LCA analysis conducted by a consulting firm, but there is no specific information about how agricultural emissions are estimated and the company reports that $0.00 \%$ of emissions are calculated using data from suppliers. The CDP report indicates a use of "mass and spend" data, but is not specific about emissions factors. The company has indicated that it has "not yet released details on the specific calculations, baseline, etc" but plans "to publish more data going forward." Until that point, however, this area is incomplete. 


\section{3: Strength/quality of target on agricultural emissions specifically}

This subcategory consists of three questions or metrics:

10. What percentage of agricultural ingredients is included in the target?

11. What sources of agricultural emissions are included in the target?

12. How is food waste --i.e., losses on-farm or between farm and manufacturing -accounted for?

\section{Assessment: Meets*}

Rationale: All metrics included in the category received a "Meets." There are clear mentions of work across the main areas of this category, including different sources of agricultural emissions (such as deforestation/land use, fertilizer/nutrients, and irrigation and tillage practices) and food waste. *There may be some inconsistency with statements about percentage of total buy covered or of key crops, but the intent of the goal as stated seems to be the entire footprint.

\section{4: Consistency with $2 \mathrm{C}$ science-based methodology and thresholds}

This subcategory consists of one question or metric:

13. What was the target setting process and what, if any, science based methodologies were utilized?

\section{Assessment: Meets**}

Rationale: General Mills worked closely with advisors at Business for Social Responsibility (BSR) and followed the WRI/CDP science-based goal standard and process. The WRI standard is generally accepted as sufficient for setting science-based targets. It is important to note two caveats however. First, General Mills' goal is in keeping with the 2-degree scenario that, until COP21, was the global target. But the global policy community has now included in the Paris agreement an additional commitment "to pursue efforts to limit the temperature increase to $1.5{ }^{\circ} \mathrm{C}$ above pre-industrial levels." If this more aggressive goal becomes the norm, General Mills' targets could be considered below science-based levels. Second, the WRI sector-based methodology has not yet calculated an agriculture sector target; this target is thus in keeping with the "other industry" SBTs used as a placeholder.

\section{5: Consistency with best practice}

This subcategory consists of one question or metric:

14. How does the target compare to the most aggressive SBTs from the Global Fortune 500 or other best practice examples

\section{Assessment: Exceeds}

Rationale: While a handful of the leading companies have set net positive targets for their business, General Mills' goals are examples of leadership -- especially with the addition of the 2050 goals in the company's April 2016 sustainability report (GRR 2015). The targets include the supply chain, which is currently rare, and now extend out to 2050, matching the global policy and science communities' time frames. 


\section{Plan to Reach Goals/Targets}

\section{1: Governance/Accountability}

This sub-category includes three metrics or questions:

15. Who in the organization is responsible for meeting GHG targets? And for measuring/estimating agricultural emissions?

16. Is there CEO or Board oversight on carbon targets?

17. Are there incentives in place for company managers, or for suppliers, to meet GHG targets?

\section{Assessment: Exceeds}

Rationale: General Mills has a strong governance structure in place on sustainability in general and clear accountability and rewards at the most senior levels for meeting GHG targets.

\subsection{Supplier engagement plans for GHG reductions}

This sub-category includes seven metrics or questions:

18. How will the company require suppliers to measurably reduce agricultural emissions and how?

19. How will the company assess pathways to reductions and opportunities to embed new sustainable agricultural practices and techniques? What external experts or partners, if any, will be consulted?

20. How will the company provide suppliers best practices on key sustainable agricultural techniques?

21. Will the company aid suppliers on implementing new technologies and techniques directly?

22. How will the progress of operational changes in the supply chain be tracked?

23. Does the company have policies and plans for achieving zero deforestation across all high forest risk commodities it sources?

24. Does the company have policies and plans for sustainably sourcing of commodities with a high environmental footprint that are relevant for its supply chain?

\section{Assessment: Exceeds}

Rationale: All metrics included in the category received a "Meets" or "Yes" response, with two critical areas receiving an "Exceeds". The latest sustainability report (GRR 2016) has a greater level of detail on projects and sharing of information across suppliers and groups of farmers. Of particular note is the series of sub-commitments, by crop, to buy $100 \%$ (by 2020) from those regions engaging in best practices and showing continuous improvement. That use of buying power is a strong lever for change. It's a robust and growing program.

\subsection{Measurement and metrics}

This sub-category includes three metrics or questions:

25. What will the process be for regularly measuring and reporting on GHGs in operations, supply chain, and downstream (scopes $1,2,3)$ ? What tools or models will be used? 
26. Will supplier-level agricultural emissions be tracked directly (vs. estimated from total ingredient yields across all suppliers of a given ingredient)? Will the company provide tools/assistance to suppliers to track their GHGs?

27. What is the process for assessing and reporting data on carbon reductions, particularly Scope 3? (e.g., is it certified by a third-party for data legitimacy?)

\section{Assessment: Meets}

Rationale: All metrics included in the category received a "Meets." The company has metrics and tools in place for GHG tracking in general (using CDP and GRI in particular), but supplier emissions tracking is not addressed quite as clearly.

\subsection{Interim goals and target adjustments/flexibility}

This sub-category includes four metrics or questions:

28. Are there targets in place for interim years?

29. What are the interim targets and for which parts of the value chain?

30. How will the company incorporate the evolving science on climate change?

31. Is there a process in place to re-set or re-establish the goals before the target year if necessary?

\section{Assessment: Meets}

Rationale: With the addition of the long-term (2050) target, established in the April 2016 Global Responsibility Report, the original 2025 goal is arguably now an interim target. The \% of spend targets for 2020, issued in 2013 , are also interim targets, so long as the definition of "sustainably source" includes reductions of GHGs in line with the targets.

\subsection{Transparency and communications}

This sub-category includes two metrics or questions:

1. Is the information on GHG reduction targets and plans available publicly in a transparent and accessible manner?

2. How will updates on implementation progress be shared? How frequently?

\section{Assessment: Meets}

Rationale: Both metrics included in the category received a "Meets". The company is transparent about the goals and states clearly it will report annually on progress. 


\section{Summary Scoring for General Mills}

\begin{tabular}{|c|c|c|}
\hline Category\# & Category & Assessment \\
\hline 1.1 & $\begin{array}{l}\text { Base information on the target and inclusion of scope } 3 \\
\text { (primarily agricultural emissions) }\end{array}$ & Meets \\
\hline 1.2 & Strength of data behind targets & Fails/Unknown \\
\hline 1.3 & $\begin{array}{l}\text { Strength/quality of target on agricultural emissions } \\
\text { specifically }\end{array}$ & Meets* \\
\hline 1.4 & $\begin{array}{l}\text { Consistency with } 2 \mathrm{C} \text { science-based methodology and } \\
\text { thresholds }\end{array}$ & Meets* \\
\hline 1.5 & Consistency with best practice & Exceeds \\
\hline 2.1 & Governance/Accountability & Exceeds \\
\hline 2.2 & Supplier engagement plans for GHG reductions & Exceeds \\
\hline 2.3 & Measurement and Metrics & Meets \\
\hline 2.4 & Interim goals and target adjustments/flexibility & Meets \\
\hline 2.5 & Transparency and communications & Meets \\
\hline
\end{tabular}




\section{ASSESSMENT OF KELLOGG'S GHG TARGETS AND PLANS}

Below is a summary of the assessment at the category level. For a more detailed look at the assessment of each of the 33 questions, please see the spreadsheet included as Appendix A, which also includes information about where in the public documents WES sourced the data.

\section{Robustness of Target Setting}

\section{1: Base Information on the Target and Inclusion of Scope 3}

This sub-category includes five metrics or questions:

1. What is the target GHG reduction percentage?

2. Is the target based on absolute or intensity calculations?

3. What is the timeline of the target (baseline, due date)?

4. What parts of the value chain are included in the target?

5. How is the target divided amongst the value chain parts?

Assessment: Meets

Rationale: All metrics included in the category received a "Meets" or "Yes" response.

\section{2: Strength of data behind targets}

This subcategory consists of four questions or metrics:

6. Does the company have GHG emission data with percentages broken down by scope and/or value chains?

7. How is data on agricultural emissions reported and analyzed?

8. How are agricultural emissions data calculated?

9. What is the quality of company's data including agricultural emissions data?

Assessment: Meets

Rationale: This category looks at how solid the data behind the target is, asking if the company has a reasonable ability to assess its value chain GHG emissions and how it is estimating agricultural emissions specifically. All metrics included in the category received a "Meets" or "Yes" response.

\section{3: Strength/quality of target on agricultural emissions specifically}

This subcategory consists of three questions or metrics:

10. What percentage of agricultural ingredients is included in the target?

11. What sources of agricultural emissions are included in the target?

12. How is food waste --i.e., losses on-farm or between farm and manufacturing -accounted for? 
Rationale: All metrics included in the category received a "Meets" or "Yes" response. For metric 10, a large majority of suppliers (75-80\%) and supply chain spending (85\%) are included, which is certainly much further ahead than most companies. But if the targets only apply to $80 \%$ of the supply chain, then they will not reach science-based reduction levels for the full value chain (unless the targets were deliberately set to make up the difference by shooting for a more-than-SBT level of reduction). Over time, the longer-term plan for these targets, and the execution plans, must move toward $100 \%$ of suppliers, or the targets will need to be adjusted to reflect the incomplete coverage.

\subsection{Consistency with $2 \mathrm{C}$ science-based methodology and thresholds}

This subcategory consists of three questions or metrics:

13. What was the target setting process and what, if any, science based methodologies were utilized target?

\section{Assessment: Meets**}

Rationale: Kellogg's utilized all major methods of setting science-based targets (WRI, WWF, and underlying IPCC data) and these are generally accepted as sufficient for setting SBTs. It is important to note two caveats however. First, Kellogg's goal is in keeping with the 2degree scenario that, until COP21, was the global target. But the global policy community has now included in the Paris agreement an additional commitment "to pursue efforts to limit the temperature increase to $1.5^{\circ} \mathrm{C}$ above pre-industrial levels." If this more aggressive goal becomes the norm, Kellogg's targets could be considered below science-based levels. Second, neither the $3 \%$ solution nor SDA have (yet) calculated an agriculture sector target; thus it is uncertain if the 2050 target for supply chain will fit that methodology (but as Kellogg's notes, its 2015 baseline is more aggressive than the 2010 IPCC starting point). We look then to the company's intended process for staying up to date (metrics 30-31).

\section{5: Consistency with best practice}

This subcategory consists of one question or metric:

14. How does the target compare to the most aggressive SBTs from the Global Fortune 500 or other best practice examples?

\section{Assessment: Exceeds}

Rationale: The target is leading in the agriculture sector and in keeping with best practice across other sectors that have set aggressive targets. Kellogg has already delivered $12 \%$ reduction in manufacturing. The additional scope 1 and 2 target of 15\% (normalized) for 2020 and the $50 \%$ low-carbon energy targets are strong. While some large companies have gone further to target $100 \%$ renewable or net positive on carbon, the inclusion here of supply chain emissions in science-based targets is currently rare. 


\section{Plan to Reach Goals/Targets}

\subsection{Governance/Accountability}

This sub-category includes three metrics or questions:

15. Who in the organization is responsible for meeting GHG targets? And for measuring/estimating agricultural emissions?

16. Is there CEO or Board oversight on carbon targets?

17. Are there incentives in place for company managers, or for suppliers, to meet GHG targets?

Assessment: Meets

Rationale: All metrics included in the category received a "Meets" or "Yes" response based on the company's corporate responsibility report or its CDP report.

\subsection{Supplier engagement plans for GHG reductions}

This sub-category includes seven metrics or questions:

18. How will the company require suppliers to measurably reduce agricultural emissions and how?

19. How will the company assess pathways to reductions and opportunities to embed new sustainable agricultural practices and techniques? What external experts or partners, if any, will be consulted?

20. How will the company provide suppliers best practices on key sustainable agricultural techniques?

21. Will the company aid suppliers on implementing new technologies and techniques directly?

22. How will the progress of operational changes in the supply chain be tracked?

23. Does the company have policies and plans for achieving zero deforestation across all high forest risk commodities it sources?

24. Does the company have policies and plans for sustainably sourcing of commodities with a high environmental footprint that are relevant for its supply chain?

\section{Assessment: Meets}

Rationale: All metrics included in the category received a "Meets" or "Yes" based on company's own disclosures as well as information provided through footprint tracking tools such as Field to Market.

\subsection{Measurement and metrics}

This sub-category includes three metrics or questions:

25. What will the process be for regularly measuring and reporting on GHGs in operations, supply chain, and downstream (scopes $1,2,3$ )? What tools or models will be used?

26. Will supplier-level agricultural emissions be tracked directly (vs. estimated from total ingredient yields across all suppliers of a given ingredient)? Will the company provide tools/assistance to suppliers to track their GHGs?

27. What Is the process for assessing and reporting data on carbon reductions, particularly Scope 3? (e.g., is it certified by a third-party for data legitimacy?) 
Assessment: Meets

Rationale: All metrics included in the category received a "Meets." The company is clear about the processes, models, emissions estimates, and the role of CDP.

\subsection{Interim goals and target adjustments/flexibility}

This sub-category includes four metrics or questions:

28. Are there targets in place for interim years?

29. What are the interim targets and for which parts of the value chain?

30. How will the company incorporate the evolving science on climate change?

31. Is there a process in place to re-set or re-establish the goals before the target year if necessary?

Assessment: Exceeds

Rationale: Two of the four metrics included in the category received a "Meets" or "Yes" response and two of the four received "Exceeds", which aligns with the definition for Exceeds for the category. Kellogg's is clear about working with industry and NGOs to develop SBTs for agriculture and to revisit its goals as science evolves.

\subsection{Transparency and communications}

This sub-category includes two metrics or questions:

32. Is the information on GHG reduction targets and plans available publicly in a transparent and accessible manner?

33. How will updates on implementation progress be shared? How frequently?

Assessment: Meets

Rationale: Both metrics included in the category received a "Meets." Kellogg is clear on filing with CDP and reporting on progress annually. 


\section{Summary Scoring for Kellogg}

\begin{tabular}{|c|c|c|}
\hline Category \# & Category & Assessment \\
\hline 1.1 & $\begin{array}{l}\text { Base information on the target and inclusion of scope } 3 \\
\text { (primarily agricultural emissions) }\end{array}$ & Meets \\
\hline 1.2 & Strength of data behind targets & Meets \\
\hline 1.3 & $\begin{array}{l}\text { Strength/quality of target on agricultural emissions } \\
\text { specifically }\end{array}$ & Meets* \\
\hline 1.4 & $\begin{array}{l}\text { Consistency with } 2 \mathrm{C} \text { science-based methodology and } \\
\text { thresholds }\end{array}$ & Meets** \\
\hline 1.5 & Consistency with best practice & Exceeds \\
\hline 2.1 & Governance/Accountability & Meets \\
\hline 2.2 & Supplier engagement plans for GHG reductions & Meets \\
\hline 2.3 & Measurement and Metrics & Meets \\
\hline 2.4 & Interim goals and target adjustments/flexibility & Exceeds \\
\hline 2.5 & Transparency and communications & Meets \\
\hline
\end{tabular}




\section{RECOMMENDATIONS, BEST PRACTICES FOR FOOD COMPANIES SETTING GHG TARGETS}

The Assessment Framework for Science-based Targets (SBTs) and Plans includes 33 questions/metrics in 10 categories (see appendices for the full framework). The company's ability to answer these questions will indicate (a) whether the targets themselves are in line with the current science on necessary carbon reductions to meet the global 2-degree threshold, and (b) whether the company is well prepared to execute a plan to achieve those science-based emissions reductions.

For some questions, such as whether there's a goal in place, the "best practice" is binary - it's either there or not. For most however, the actions a company takes will fall along a spectrum of likelihood to fail, meet, or exceed what's necessary for achieving science based targets. In this part of the report we describe primarily what exceeding in these core areas would look like, thus improving the likelihood of a good outcome. We suggest here best practice for each of the 10 sections and highlight four of the more important recommendations that go beyond current practice and would enable a company to take a leadership position.

\section{Must-Have Requirements}

A subset of the metrics is necessary for setting robust science-based goals. For the following assessment sections, companies must either "meet" or "exceed" the definitions established for the metrics included.

- Section 1.1 - Base information on the target and inclusion of scope 3 (primarily agricultural emissions). This section is primarily to establish the basics of the target: the percentage reduction, whether that reduction is absolute or relative, the timeline/due date, whether agricultural emissions are included, and how the goal is applied to the value chain. Best practice here is straightforward: establishing targets publicly and make the scope and inclusion of agricultural emissions clear.

- Section 1.2 - Strength of data behind targets. This section assesses whether the company has a strong grasp of its value chain GHG emissions (e.g., how much is upstream with suppliers) and how it measures those agricultural emissions in particular. In this case there is a gap between theoretical best practice and what's available today. For the most part, agricultural emissions are calculated by multiplying total crop yield data by estimates of the emissions associated with a particular crop based on academic studies of, for example, a sample farm in one region. Over time, best practice will need to be farm-level data so companies can establish benchmarks and truly track progress.

Next gen best practice recommendation 1: Begin to build

the capabilities and tools to capture farm-level data. Ask

suppliers to track and communicate farm-level GHG data

annually. 
- Section 1.3 - Strength/quality of target on agricultural emissions specifically. This section assesses whether the agricultural emissions target covers all inputs, includes all major sources of emissions from agriculture (deforestation, livestock, fertilizer, etc.), and takes into account losses and waste in the value chain. Today many companies set their goals for their top crops or inputs. Best practice is to set a goal (and process to meet the goal) for all inputs, to explicitly address the major sources, and to include emissions for the entire farm/supplier production (not just the total purchased or reaching the food processor, which would ignore waste.

- Section 1.4 - Consistency with 2C science-based methodology and thresholds. This section includes just one critical question about whether the company following a respected and tested methodology to set a science-based target (SBT). The major tools for SBT development include:

- The $3 \%$ solution, built by WWF and McKinsey, which covers the period from 2010 to 2020.

- The Low Carbon Economy Index from PwC which annually calculates the reduction in carbon intensity needed globally to meet the 2-degree threshold.

- The Sectoral Decarbonization Approach, developed primarily by World Resources Institute, which overlays onto the science-based reductions a sector-level adjustment based on the economics of carbon reductions in each sector (thus some sectors are given recommendations to target slower decarbonization than the first two methods would suggest).

All of these methods are based on the same data from the global scientific community assembled by the UN's Intergovernmental Panel on Climate Change (IPCC). Thus they are in essence equivalent, with some variation for the sector perspective added by WRI.

But all of that said, we suggest an important caveat. Setting goals in line with the science using one of these methods should be a minimum barrier, or floor, for goal setting...just as the recommended and prescribed dose of a medicine is not negotiable.

We do see a fundamental hurdle to global achievement of the 2-degree mark: some countries, sectors, and companies will clearly go slower on reductions. So we recommend that best practice would mean going even faster and leading value chains and sectors down the decarbonization path. The more aggressive approach would build a buffer zone for emissions reduction performance and, on a value chain level, may actually be more economic. (See best practice recommendation 2 below).

\section{Next Level Performance}

The following sections of the Assessment Framework are highly recommended to take the goalsetting and action plans further.

- Section 1.5 - Consistency with Best Practice. This section reflects an assessment by WES that compares the company's goals to the goals of the world's largest companies, using our proprietary database www.pivotgoals.com. Combining the recommendations from section 
1.4 and 1.5, we suggest going further. The kinds of goals that go beyond SBT level include time-based $100 \%$ renewable targets or "net positive" and "regenerative" targets.

Next gen best practice recommendation 2: Set more

aggressive goals that exceed the SBT definitions in

order to build in a buffer zone and move sectors and

value chains along the path.

- Section 2.1 - Governance/Accountability. This section assesses the organizational commitment to the target, looking at who owns the target, whether the CEO and board are involved, and whether incentives are in place for leaders to reach the target. Best practice here is fairly self-explanatory - senior leaders should be responsible for meeting the numbers, and both execs and operational managers should have compensation and bonuses on the line.

- Section 2.2 - Supplier engagement plans for GHG reductions. This section contains the critical action plan questions about how the reductions in agricultural emissions in the supply chain will happen. We include questions about how the company will identify agricultural best practices, share those with suppliers, help them implement best practices, and track progress. Best practice for this section includes working with NGO experts to understand and identify sustainable agriculture techniques (no-tillage, cover crops, nutrient and manure management, etc.), developing processes and forums for sharing these with suppliers, and providing human, technological, and even financial capital to help accelerate the change up stream.

Next gen best practice recommendation 3: Set aside

human capital and expertise to work with the suppliers,

and establish a loan fund to invest with less technologically

enabled suppliers to help them implement precision

agriculture and other new technologies.

- Section 2.3 - Measurement and Metrics. This section assesses the company's data collection around GHG performance - with some overlap from section 1.3 - and looks at how the company will report on these metrics. Best practice is to follow GRI and report to CDP regularly and to ask suppliers to do the same. Next Gen best practice recommendation 1 applies here as well.

- Section 2.4 - Interim Goals and Target Adjustment/flexibility. This section assesses how prepared the company is to adjust its targets and the process to do so. Best practice is to set interim targets on the path to long-term reductions in line with science and to regularly review the latest science and estimates on the pace of GHG reduction required.

- Section 2.5 - Transparency and Communications. This section simply assesses whether the company is providing information on all of the above areas transparently and regularly. Best practice is to clearly establish a public communication plan and report on the status of progress annually. 


\section{For Companies Just Getting Started}

For companies in the Food \& Ag sector just starting the journey to science-based goal setting, we recommended some specific steps, led primarily by the sustainability executives:

- Self-assess your target and program: utilize the Assessment Framework to score your current emissions target and plans to reach the target. Highlight where you fail to meet the requirements and use that outcome as input to your next iteration on goal setting. If you are well into the process, consider self-assessing your publicly available information and compare your scores and/or utilize a third-party to provide an assessment.

- Communicate with your management team: take the outcomes of your assessment(s) back to your greater management team and focus on where you can improve your goal(s) and your management systems in place to help reach your goal

- Recalibrate your goals: if needed, reset your goals and strengthen your plans based on the assessments made and the internal feedback from the management team

\section{Recommendations for Food and Agriculture Sector}

The reduction of emissions in order to abate climate change is most certainly a "we are all in this together" issue for the Food and Agriculture sector. Thus, collaborating is an imperative task and one that likely will "raise all ships." The following are recommended specific steps:

- Best practices database: create an industry-wide, open platform database of best practices, e.g. emissions measuring technologies, that companies can learn from and take back to their programs. This information should likely be housed with an NGO or academic partner.

- Meeting of the minds: host an industry-wide gathering to provide a forum for communicating best practices, discussing issues and opportunities, and fostering a collaborative and transparent process for reducing scope 3 emissions in the sector.

- Communicate collective progress: establish a means for communicating company and sector progress towards goals and improvements in the plans to reach those goals. For example, the sector could produce an annual survey or report for Oxfam to curate into an industry-wide annual update.

Next gen best practice recommendation 4: Create a

best practices database; host an industry-wide gathering

to discuss best practices, issues, and opportunities; and

communicate annual progress out to the world

There is a long way to go in corporate goal setting around emissions reductions. Leaders like the General Mills and Kellogg have taken the initial steps to set and reach a science-based emission reduction goal for their own operations and their suppliers. This Assessment Framework is meant to help others do the same. 


\section{CONCLUSIONS}

Both Kellogg and General Mills scored well on both the targets and the plans to reach the targets. The few ratings of "fails/unknown" resulted mainly from a lack of information available in the public domain. This implies that the companies may either have the necessary information and data in place but have not shared that information or could work to develop the information. A full scorecard containing "Meets" and "Exceeds" marks is close.

Based on the current scoring assessment, both Kellogg and General Mills should be considered leaders in GHG goal setting in the Food and Ag industry and also strong actors when compared across all industries (based on our benchmark analyses and comparison of goal setting from Pivot Goals data at www.pivotgoals.com). Setting a numeric goal for the supply chain is an emerging best practice and still unusual. By that standard alone, this represents leadership.

While some of the details of how the companies will reach the goals are still to be determined and much of the uncertainty is inherent in the state of play on agricultural emissions measurement -- these targets are strong. That said, it will be critical to execute with a robust operational plan, with metrics, interim goals, and repeated checkpoints. This last consideration is not a minor one: the global policy community has already moved the discussion from 2 degrees to a soft target of 1.5 degrees, which would imply that countries and companies will need even more aggressive targets. We highly recommend a regular review of the pace of decarbonization required to match the science.

We also hope these companies will lean in to their leadership and some of the "next gen" practices we suggest above. In the future, with technology and data improvements, we should see even better data (farm-level) and perhaps even more aggressive targets (beyond SBT) to drive systemic change. 


\section{APPENDICES}

\section{APPENDIX A - Kellogg and General Mills framework assessment detail}

\begin{tabular}{|c|c|c|c|c|c|c|c|}
\hline & $\begin{array}{l}\text { BUSTNESS OF } \\
\text { ET SETTING }\end{array}$ & \begin{tabular}{|l} 
Data \\
Format
\end{tabular} & $\begin{array}{l}\text { GENERAL MILLS } \\
\text { RESPONSE }\end{array}$ & \begin{tabular}{|l} 
Scoring \\
Rubric
\end{tabular} & $\begin{array}{l}\text { Assess } \\
\text { ment }\end{array}$ & $\begin{array}{l}\text { Reasoning/Clar } \\
\text { ifications }\end{array}$ & $\begin{array}{l}\text { Source (public } \\
\text { information) }\end{array}$ \\
\hline & $\begin{array}{l}\text { ase information on the ta } \\
\text { arily agricultural emissic }\end{array}$ & $\begin{array}{l}\text { arget ano } \\
\text { ons) }\end{array}$ & inclusion of scope 3 & $E / M / F$ & Meets & & \\
\hline 1 & $\begin{array}{l}\text { What is the target GHG } \\
\text { reduction? }\end{array}$ & $\%$ & $\begin{array}{l}28 \% \text { by } 2025,41 \text { to } 72 \% \text { by } \\
2050\end{array}$ & Yes/No & Yes & $\begin{array}{l}\text { Yes, target is } \\
\text { set }\end{array}$ & \begin{tabular}{|l} 
Public \\
statements: \\
"General Mills \\
makes new \\
commitment on \\
climate \\
change", \\
Aug.31, 2015; \\
2050 goal from \\
2016 \\
sustainability \\
report
\end{tabular} \\
\hline 2 & $\begin{array}{l}\text { Is the target for absolute } \\
\text { emissions } \\
\text { (vs.relative/intensity)? }\end{array}$ & Yes/No & Absolute & Yes/No & Yes & $\begin{array}{l}\text { It is specifically } \\
\text { stated as an } \\
\text { absolute goal. }\end{array}$ & $\begin{array}{l}\text { Public } \\
\text { statements: } \\
\text { "General Mills } \\
\text { makes new } \\
\text { commitment on } \\
\text { climate } \\
\text { change", } \\
\text { Aug.31, 2015; } \\
2050 \text { goal from } \\
2016 \\
\text { sustainability } \\
\text { report }\end{array}$ \\
\hline 3 & $\begin{array}{l}\text { What is the timeline of } \\
\text { the target? Baseline? } \\
\text { Starting when and by } \\
\text { when? }\end{array}$ & Years & Baseline: 2010; Due: 2025 & NA & $\mathrm{NA}$ & $\begin{array}{l}\text { The baseline } \\
\text { and due date } \\
\text { are specifically } \\
\text { provided }\end{array}$ & $\begin{array}{l}\text { Public } \\
\text { statements: } \\
\text { "General Mills } \\
\text { makes new } \\
\text { commitment on } \\
\text { climate } \\
\text { change", } \\
\text { Aug.31, 2015; } \\
2050 \text { goal from } \\
2016 \\
\text { sustainability } \\
\text { report } \\
\end{array}$ \\
\hline 4 & $\begin{array}{l}\text { What parts of value } \\
\text { chain are included in the } \\
\text { target? Are scope } 3 \\
\text { and/or agricultural } \\
\text { emissions included? }\end{array}$ & $\begin{array}{l}\text { Details; } \\
\text { Yes/No }\end{array}$ & Entire Value Chain & Yes/No & Yes & $\begin{array}{l}\text { "across the } \\
\text { entire value } \\
\text { chain" is } \\
\text { specifically } \\
\text { stated }\end{array}$ & $\begin{array}{l}\text { Public } \\
\text { statements: } \\
\text { "General Mills } \\
\text { makes new } \\
\text { commitment on } \\
\text { climate } \\
\text { change", } \\
\text { Aug.31, 2015; } \\
2050 \text { goal from } \\
2016 \\
\text { sustainability } \\
\text { report }\end{array}$ \\
\hline 5 & $\begin{array}{l}\text { How is the target } \\
\text { divided amongst value } \\
\text { chain parts (all the } \\
\text { same target or } \\
\text { variable)? }\end{array}$ & Details & $\begin{array}{l}\text { Implied that it is shared: } \\
\text { "collaboration with } \\
\text { stakeholders across our } \\
\text { value chain, including } \\
\text { growers, suppliers, industry } \\
\text { groups, customers, as well as } \\
\text { other partners" }\end{array}$ & $\mathrm{E} / \mathrm{M} / \mathrm{F}$ & Meets & $\begin{array}{l}\text { The } \\
\text { collaboration } \\
\text { statement } \\
\text { implies the goal } \\
\text { is } 28 \% \text { across } \\
\text { all stages and } \\
\text { will be led by } \\
\text { General Mills, } \\
\text { but it is unclear } \\
\text { if that means } \\
28 \% \text { for every }\end{array}$ & $\begin{array}{l}\text { Public } \\
\text { statements: } \\
\text { "General Mills } \\
\text { makes new } \\
\text { commitment on } \\
\text { climate } \\
\text { change", } \\
\text { Aug.31, 2015; } \\
2050 \text { goal from } \\
2016 \\
\text { sustainability }\end{array}$ \\
\hline
\end{tabular}




\begin{tabular}{|c|c|c|c|c|c|c|c|}
\hline & & & & & & \begin{tabular}{|l|} 
supplier or there \\
will be varied \\
targets (see line \\
10 as well)
\end{tabular} & report \\
\hline \multicolumn{3}{|c|}{ 1.2 Strength of data behind targets } & & $E / M / F$ & \multicolumn{2}{|c|}{ Fails/Unknown } & \\
\hline 6 & $\begin{array}{l}\text { Does the company have } \\
\text { GHG emission data with } \\
\text { percentages broken } \\
\text { down by scope and/or } \\
\text { value chain stage (e.g. } \\
70 \% \text { supply chain; } 25 \% \\
\text { operations; } 5 \% \text { EOL) } \\
\end{array}$ & $\begin{array}{l}\% \text { with } \\
\text { detail }\end{array}$ & Yes & Yes/No & \begin{tabular}{|l|} 
Yes, \\
Meets
\end{tabular} & $\begin{array}{l}\text { Company has } \\
\text { clear } \\
\text { understanding } \\
\text { of GHG (and } \\
\text { water) footprint } \\
\text { across } 7 \text { value } \\
\text { chain stages } \\
\end{array}$ & $\begin{array}{l}\text { Global } \\
\text { Responsibility } \\
\text { 2015, p.5 }\end{array}$ \\
\hline 7 & $\begin{array}{l}\text { How is data on } \\
\text { agricultural emissions } \\
\text { reported and analyzed? } \\
\text { (e.g., does the company } \\
\text { have data on } \\
\text { agricultural emissions, } \\
\text { is the data aggregated } \\
\text { or broken down by } \\
\text { ingredient/commodity or } \\
\text { by category (dairy vs. } \\
\text { row crops)?) }\end{array}$ & $\begin{array}{l}\% \text { with } \\
\text { detail }\end{array}$ & $\begin{array}{l}\text { General Mills has conducted } \\
\text { field tests with GHG } \\
\text { measurement with CAP2ER } \\
\text { (dairy) and with Field to } \\
\text { Market in numerous regions } \\
\text { and crops, including wheat in } \\
\text { Idaho, sugar beets in Red } \\
\text { River Valley, and corn in } \\
\text { Wisconsin }\end{array}$ & $\mathrm{E} / \mathrm{M} / \mathrm{F}$ & \begin{tabular}{|l|} 
Fails/U \\
nknown
\end{tabular} & \begin{tabular}{|l|} 
The pilot tests \\
would indicate \\
some data on \\
some key \\
ingredients, but \\
it's unclear if \\
General Mills \\
has \\
calculated/estim \\
ated total ag \\
emissions to \\
provide a \\
baseline for the \\
goal. The \\
company's CDP \\
report discusses \\
an LCA analysis \\
conducted by a \\
consulting firm, \\
but there is not \\
specific \\
information \\
about how \\
agricultural \\
emissions are \\
estimated and \\
the company \\
reports that \\
0.00\% of \\
emissions are \\
calculated using \\
data from \\
suppliers. \\
\end{tabular} & $\begin{array}{l}\text { Global } \\
\text { Responsibility } \\
\text { 2015, p.52-56 }\end{array}$ \\
\hline 8 & $\begin{array}{l}\text { How are agricultural } \\
\text { emissions data } \\
\text { calculated? (e.g., actual } \\
\text { yield combined with } \\
\text { emissions estimated } \\
\text { from academic studies } \\
\text { of specific crops)? }\end{array}$ & Detail & $\begin{array}{l}\text { From CDP: "Data is from an } \\
\text { assessment completed in } \\
2015 \text { by LCA consultancy } \\
\text { Quantis and includes } \\
\text { agriculture, packaging supply } \\
\text { chain and ingredient } \\
\text { manufacturing. A } \\
\text { combination of mass and } \\
\text { spend data from the latest } \\
\text { fiscal year (F14) was used for } \\
\text { LCA-based calculations." }\end{array}$ & $\mathrm{E} / \mathrm{M} / \mathrm{F}$ & Meets* & \begin{tabular}{|l|} 
There is the \\
basic \\
information from \\
the CDP report \\
that indicates \\
the company \\
has used mass \\
of inputs and \\
presumably \\
some emission \\
factors, but the \\
specifics are \\
unclear \\
\end{tabular} & $\begin{array}{l}\text { Global } \\
\text { Responsibility } \\
2015, \text { p.52-56 }\end{array}$ \\
\hline 9 & \begin{tabular}{|l|} 
What is the quality of \\
company's data \\
including agricultural \\
emissions data (e.g., \\
what is baseline year of \\
solid data for GHGs, is \\
data third party \\
verified?)
\end{tabular} & Detail & $\begin{array}{l}\text { Some Field to Market pilots } \\
\text { extend back } 4-5 \text { years; the } \\
\text { company says it has "not yet } \\
\text { released details on the } \\
\text { specific calculations, } \\
\text { baseline, etc." but plans "to } \\
\text { publish more data going } \\
\text { forward." }\end{array}$ & $\mathrm{E} / \mathrm{M} / \mathrm{F}$ & \begin{tabular}{|l|} 
Fails/U \\
nknown
\end{tabular} & \begin{tabular}{|l|} 
The pilots tests \\
indicate some \\
data for 5 years, \\
but unclear \\
what portion of \\
ag emissions \\
can be \\
estimated and \\
how far back. \\
More data and \\
information is \\
\end{tabular} & $\begin{array}{l}\text { Global } \\
\text { Responsibility } \\
2015, \text { p.52-56 }\end{array}$ \\
\hline
\end{tabular}




\begin{tabular}{|c|c|c|c|c|c|c|c|}
\hline & & & & & & \begin{tabular}{|l|} 
forthcoming, but \\
until that point, \\
this metric must \\
be shown as \\
incomplete. \\
\end{tabular} & \\
\hline \multicolumn{4}{|c|}{ 1.3 Strength/quality of target on agricultural emissions specifically } & $E / M / F$ & \multicolumn{2}{|c|}{ Meets $^{*}$} & \\
\hline 10 & $\begin{array}{l}\text { What percentage of } \\
\text { agricultural ingredients } \\
\text { is included in the target } \\
\text { (By volume of } \\
\text { ingredients? By CO2e } \\
\text { of ag emissions?) }\end{array}$ & $\%$ & \begin{tabular}{l|l|} 
Goal is "to reduce & E \\
greenhouse gas emissions & \\
across our entire value chain"
\end{tabular} & $\mathrm{E} / \mathrm{M} / \mathrm{F}$ & Meets $^{*}$ & $\begin{array}{l}{ }^{\star} \text { There could be } \\
\text { some conflict } \\
\text { with previous } \\
\text { statements that } \\
\text { cover } 50 \% \text { of } \\
\text { total buy, but we } \\
\text { read the new } \\
\text { statement as } \\
\text { committing to } \\
\text { cuts across } \\
\text { either all } \\
\text { ingredients or } \\
\text { through larger } \\
\text { than } 28 \% \text { cuts } \\
\text { on priority } \\
\text { ingredients to } \\
\text { meet the total } \\
\text { reduction goal }\end{array}$ & \begin{tabular}{|l|} 
Public \\
statements: \\
"General Mills \\
makes new \\
commitment on \\
climate \\
change", \\
Aug.31, 2015
\end{tabular} \\
\hline 11 & $\begin{array}{l}\text { What sources of } \\
\text { agricultural emissions } \\
\text { are included in the } \\
\text { target? (See list below } \\
\text { for major sources) }\end{array}$ & Detail & \begin{tabular}{|l|l} 
"By leveraging the Field to & $\mathrm{E}$ \\
Market framework, growers \\
are able to collect data that \\
will help to guide everyday \\
decisions related to irrigation, \\
tillage, crop rotation and \\
nutrient management." Value \\
chain data in report also \\
mentions deforestation and \\
land use
\end{tabular} & $\mathrm{E} / \mathrm{M} / \mathrm{F}$ & Meets & \begin{tabular}{|l|} 
The corporate \\
climate policy \\
outlines the \\
company \\
approach to \\
reduce \\
emissions \\
across the value \\
chain
\end{tabular} & $\begin{array}{l}\text { Policy on } \\
\text { Climate, Global } \\
\text { Responsibility } \\
2015 \text { (p.7) }\end{array}$ \\
\hline & \multicolumn{7}{|c|}{$\begin{array}{l}\text { a. Deforestation and other land use change b. livestock emissions (both enteric fermentation and manure } \\
\text { management) c. Rice production d. nitrogen fertilizer application (both synthetic and manure); e. peatland drainage; f. } \\
\text { on farm energy use, and g. upstream fertilizer production, h. other as applicable }\end{array}$} \\
\hline 12 & $\begin{array}{l}\text { How is food waste -- } \\
\text { i.e., losses on-farm or } \\
\text { between farm and } \\
\text { manufacturing -- } \\
\text { accounted for? (i.e., is } \\
\text { all farm production } \\
\text { included or just } \\
\text { emissions related to } \\
\text { inputs that are utilized) }\end{array}$ & Detail & \begin{tabular}{|l|} 
"Contribute to cross-industry \\
efforts on food waste reduction \\
and donate surplus food. \\
Reduce food waste, which, \\
when landfilled, creates \\
methane - a GHG 20 times \\
more potent than carbon \\
dioxide."
\end{tabular} & $\mathrm{E} / \mathrm{M} / \mathrm{F}$ & Meets & \begin{tabular}{|l|} 
Food waste is \\
addressed as a \\
cross-industry \\
issue that \\
General Mills \\
will contribute \\
to, but no \\
specifics are \\
given.
\end{tabular} & $\begin{array}{l}\text { Policy on } \\
\text { Climate }\end{array}$ \\
\hline \multicolumn{4}{|c|}{$\begin{array}{l}\text { 1.4 Consistency with } 2 C \text { science-based methodology and } \\
\text { thresholds }\end{array}$} & $E / M / F$ & \multicolumn{2}{|c|}{ Meets $^{\star \star}$} & \\
\hline 13 & $\begin{array}{l}\text { What was the target } \\
\text { setting process and } \\
\text { what, if any, science } \\
\text { based methodologies } \\
\text { were utilized? (e.g., } \\
\text { does the target align } \\
\text { with carbon budget } \\
\text { estimations from IPCC, } \\
\text { was the target derived } \\
\text { through straight-line } \\
\text { reductions or sector- } \\
\text { based methodologies } \\
\text { etc.?) }\end{array}$ & Details & \begin{tabular}{|l|} 
"We worked closely with \\
Business for Social \\
Responsibility (BSR) to \\
calculate a science-based goal \\
(to WRI standards)". The \\
company's new sustainability \\
report, indicates a new, clear \\
2050 goal tht will be "in line \\
with scientific consensus"
\end{tabular} & $\mathrm{E} / \mathrm{M} / \mathrm{F}$ & Meets & \begin{tabular}{|l|} 
The WRI \\
standard (in \\
conjunction \\
with CDP) is \\
generally \\
accepted as \\
sufficient for \\
setting \\
science-based \\
targets. \\
**CAVEATS: \\
(1) The Global \\
policy \\
community has \\
included \\
discussion of a \\
1.5 degree \\
warming \\
scenario now, \\
and these \\
goals are
\end{tabular} & \begin{tabular}{|l|} 
Public \\
statements: \\
"General Mills \\
makes new \\
commitment on \\
climate \\
change", \\
Aug.31, 2015
\end{tabular} \\
\hline
\end{tabular}




\begin{tabular}{|c|c|c|c|c|c|c|c|}
\hline & & & & & & $\begin{array}{l}\text { targeting the 2- } \\
\text { degree } \\
\text { scenario. (2) } \\
\text { The sector- } \\
\text { based } \\
\text { methodology } \\
\text { has not yet } \\
\text { calculated an } \\
\text { agriculture } \\
\text { sector target; } \\
\text { this target is } \\
\text { thus in keeping } \\
\text { with the "other } \\
\text { industry" SBTs } \\
\text { used as a } \\
\text { placeholder. }\end{array}$ & \\
\hline \multicolumn{3}{|c|}{ 1.5 Consistency with best practice } & & & \multicolumn{2}{|l|}{ Exceeds } & \\
\hline 14 & \multicolumn{2}{|c|}{$\begin{array}{l}\text { How does the target compare to } \\
\text { the most aggressive SBTs from } \\
\text { the Global Fortune } 500 \text { or other } \\
\text { best practice examples (e.g. goals } \\
\text { on renewable energy, waste } \\
\text { reduction, deforestation etc.) }\end{array}$} & NA - WES analysis & & Exceeds & $\begin{array}{l}\text { The target is } \\
\text { leading in the } \\
\text { ag sector and } \\
\text { in keeping with } \\
\text { best practice } \\
\text { across other } \\
\text { sectors that } \\
\text { have set } \\
\text { aggressive } \\
\text { targets, } \\
\text { especially with } \\
\text { the addition of } \\
\text { the } 2050 \text { goals } \\
\text { in the } \\
\text { company's } \\
\text { April } 2016 \\
\text { sustainability } \\
\text { report. While } \\
\text { some large } \\
\text { companies } \\
\text { have gone } \\
\text { further to } \\
\text { target } 100 \% \\
\text { renewable or } \\
\text { net positive on } \\
\text { carbon, the } \\
\text { inclusion here } \\
\text { of supply chain } \\
\text { emissions in } \\
\text { science-based } \\
\text { targets is } \\
\text { currently rare. }\end{array}$ & $\begin{array}{l}\text { PivotGoals and } \\
\text { WES analysis }\end{array}$ \\
\hline \multicolumn{2}{|c|}{$\begin{array}{l}\text { 2. PLAN TO REACH THE } \\
\text { GOALS/TARGETS }\end{array}$} & \multicolumn{2}{|c|}{ Data Format } & \multicolumn{3}{|c|}{ Scoring Rubric } & \\
\hline \multicolumn{3}{|c|}{2.1 Governance/Accountability } & & $E / M / F$ & \multicolumn{2}{|l|}{ Exceeds } & \\
\hline 15 & $\begin{array}{l}\text { Who in the organization } \\
\text { is responsible for } \\
\text { meeting GHG targets? } \\
\text { And for } \\
\text { measuring/estimating } \\
\text { agricultural emissions? }\end{array}$ & Detail & $\begin{array}{l}\text { The entire leadership } \\
\text { team, including Chairman } \\
\text { and CEO, EVP of supply } \\
\text { chain, Chief Sustainability } \\
\text { Officer }\end{array}$ & $\mathrm{E} / \mathrm{M} / \mathrm{F}$ & Exceeds & $\begin{array}{l}\text { This meets } \\
\text { and arguably } \\
\text { exceeds } \\
\text { expectations }\end{array}$ & $\begin{array}{l}\text { Global } \\
\text { Responsibility } \\
2015, p .5,72\end{array}$ \\
\hline 16 & $\begin{array}{l}\text { Is there CEO or Board } \\
\text { oversight on carbon } \\
\text { targets? }\end{array}$ & Yes/No & Yes & Yes/No & $\begin{array}{l}\text { Yes, } \\
\text { Meets }\end{array}$ & $\begin{array}{l}\text { This meets } \\
\text { expectations }\end{array}$ & $\begin{array}{l}\text { Global } \\
\text { Responsibility } \\
2015, \text { p.5, } 72\end{array}$ \\
\hline 17 & $\begin{array}{l}\text { Are there incentives in } \\
\text { place for company } \\
\text { managers, or for } \\
\text { suppliers, to meet GHG } \\
\text { targets? }\end{array}$ & Detail & Yes & $\mathrm{E} / \mathrm{M} / \mathrm{F}$ & Exceeds & $\begin{array}{l}\text { All employees } \\
\text { are eligible for } \\
\text { monetary } \\
\text { rewards for } \\
\text { meeting } \\
\text { efficiency } \\
\text { targets. The } \\
\text { CEO is eligible }\end{array}$ & $\begin{array}{l}\text { CDP } 2015 \\
\text { Supply Chain } \\
\text { Response }\end{array}$ \\
\hline
\end{tabular}




\begin{tabular}{|c|c|c|c|c|c|c|c|}
\hline & & & & & & $\begin{array}{l}\text { for monetary } \\
\text { rewards for } \\
\text { meeting } \\
\text { emissions and } \\
\text { energy } \\
\text { reduction } \\
\text { targets. } \\
\end{array}$ & \\
\hline \multicolumn{4}{|c|}{2.2 Supplier engagement plans for GHG reductions } & $E / M / F$ & \multicolumn{2}{|c|}{ Exceeds } & \\
\hline 18 & $\begin{array}{l}\text { How will the company } \\
\text { require suppliers to } \\
\text { measurably reduce } \\
\text { agricultural emissions } \\
\text { (e.g., what mechanisms } \\
\text { such as supplier codes } \\
\text { will be used)? }\end{array}$ & Detail & $\begin{array}{l}\text { Achieving the goals will require } \\
\text { "collaboration with stakeholders } \\
\text { across our value chain, } \\
\text { including growers, suppliers." } \\
\text { Supplier code of conduct also } \\
\text { indicates termination if no } \\
\text { compliance. }\end{array}$ & $\mathrm{E} / \mathrm{M} / \mathrm{F}$ & Meets & \begin{tabular}{|l|} 
The specifics of \\
how suppliers \\
will be required \\
to meet the $28 \%$ \\
are not explicit. \\
But the \\
combination of \\
statements and \\
policies in total \\
indicates \\
suppliers will \\
need to reach \\
the new goals. \\
\end{tabular} & $\begin{array}{l}\text { Public } \\
\text { statements: } \\
\text { "General Mills } \\
\text { makes new } \\
\text { commitment on } \\
\text { climate } \\
\text { change", } \\
\text { Aug.31, 2015; } \\
\text { Global } \\
\text { Responsibility } \\
\text { 2015, p.41; } \\
\text { Supplier Code } \\
\text { of Conduct }\end{array}$ \\
\hline 19 & $\begin{array}{l}\text { How will the company } \\
\text { assess pathways to } \\
\text { reductions and } \\
\text { opportunities to embed } \\
\text { new sustainable } \\
\text { agricultural practices } \\
\text { and techniques? What } \\
\text { external experts or } \\
\text { partners, if any, will be } \\
\text { consulted? }\end{array}$ & Detail & $\begin{array}{l}\text { General Mills uses a four stage } \\
\text { approach to work with suppliers } \\
\text { to transform their operations } \\
\text { and partners with WWF, TNC, } \\
\text { CARE, and others. }\end{array}$ & $\mathrm{E} / \mathrm{M} / \mathrm{F}$ & Meets & \begin{tabular}{|l|} 
The company \\
has established \\
a process for \\
work with \\
suppliers and \\
find \\
opportunities, \\
working with top \\
tier external \\
partners and \\
experts. \\
\end{tabular} & $\begin{array}{l}\text { Global } \\
\text { Responsibility } \\
2015 \text { (p.42) }\end{array}$ \\
\hline 20 & $\begin{array}{l}\text { How will the company } \\
\text { provide suppliers best } \\
\text { practices on key } \\
\text { sustainable agricultural } \\
\text { techniques (e.g., no- } \\
\text { tillage, cover crops, } \\
\text { rotation, nutrient } \\
\text { management, manure } \\
\text { management)? }\end{array}$ & Detail & $\begin{array}{l}\text { General Mills works with } \\
\text { suppliers and NGOs to } \\
\text { implement solutions. General } \\
\text { Mills pilots projects and } \\
\text { communicates results so that } \\
\text { the work might spread. The } \\
\text { latest sustainability report (GRR } \\
\text { 2015), released April 2016, has } \\
\text { significant detail on programs } \\
\text { for different crops. }\end{array}$ & $\mathrm{E} / \mathrm{M} / \mathrm{F}$ & \begin{tabular}{|l|} 
Exceed \\
$\mathrm{s}$
\end{tabular} & \begin{tabular}{|l|} 
The latest \\
materials from \\
the company \\
add a great deal \\
of detail around \\
the programs, \\
including work \\
in sugar beet, \\
corn, wheat, \\
oats, dairy, and \\
pollinators. The \\
company has a \\
number of \\
programs to \\
bring together \\
groups of \\
farmers and \\
suppliers in \\
different \\
categories, \\
conduct \\
assessments, \\
and find \\
opportunities for \\
improvement \\
\end{tabular} & $\begin{array}{l}\text { Global } \\
\text { Responsibility } \\
2016 \text { (p.40-58) }\end{array}$ \\
\hline 21 & $\begin{array}{l}\text { Will the company aid } \\
\text { suppliers on } \\
\text { implementing new } \\
\text { technologies and } \\
\text { techniques directly (e.g., } \\
\text { with human or financial } \\
\text { capital?) }\end{array}$ & Detail & $\begin{array}{l}\text { General Mills is engaged in a } \\
\text { number of pilot projects in } \\
\text { multiple crops and regions on } \\
\text { GHG measurement and } \\
\text { reduction, as well as direct } \\
\text { funding of projects in best } \\
\text { practices in water management. } \\
\text { There are also commitments to } \\
\text { source } 100 \% \text { of major crops } \\
\text { from regions making progress } \\
\text { on these metrics }\end{array}$ & $\mathrm{E} / \mathrm{M} / \mathrm{F}$ & \begin{tabular}{|l|} 
Exceed \\
$\mathrm{s}$
\end{tabular} & \begin{tabular}{|l|} 
While the \\
evidence of \\
direct funding \\
for new \\
technologies or \\
practices is \\
unclear, the \% \\
of spend \\
commitments to \\
buy $100 \%$ from \\
those engaging \\
in best practices
\end{tabular} & $\begin{array}{l}\text { Global } \\
\text { Responsibility } \\
2016 \text { (p.40-58) }\end{array}$ \\
\hline
\end{tabular}




\begin{tabular}{|c|c|c|c|c|c|c|c|}
\hline & & & & & & \begin{tabular}{|l|} 
(and showing \\
continuous \\
improvement) is \\
a large \\
funneling of \\
capital into more \\
sustainable \\
practices. The \\
buying power is \\
the critical \\
leverage point.
\end{tabular} & \\
\hline 22 & $\begin{array}{l}\text { How will the progress of } \\
\text { operational changes in } \\
\text { the supply chain be } \\
\text { tracked? }\end{array}$ & Detail & $\begin{array}{l}\text { General Mills uses different } \\
\text { verification techniques based } \\
\text { on the project. Third-party } \\
\text { auditors might be involved if } \\
\text { necessary. }\end{array}$ & $\mathrm{E} / \mathrm{M} / \mathrm{F}$ & Meets & $\begin{array}{l}\text { A process exists } \\
\text { for verification } \\
\text { based on each } \\
\text { project. } \\
\text { Membership in } \\
\text { organizations to } \\
\text { share supplier } \\
\text { data (e.g., } \\
\text { SEDEX) could } \\
\text { be helpful as } \\
\text { well. But details } \\
\text { are somewhat } \\
\text { lacking. }\end{array}$ & $\begin{array}{l}\text { Global } \\
\text { Responsibility } \\
2015 \\
(p .5,43,50,53)\end{array}$ \\
\hline \multicolumn{8}{|c|}{ Context of larger sustainable sourcing efforts } \\
\hline 23 & \begin{tabular}{|l|} 
Does the company have \\
policies and plans for \\
achieving zero \\
deforestation across all \\
high forest risk \\
commodities it sources?
\end{tabular} & Yes/No & $\begin{array}{l}\text { "We are committed to achieving } \\
\text { zero net deforestation in our } \\
\text { high-risk supply chains" }\end{array}$ & Yes/No & Yes & $\begin{array}{l}\text { Yes, policies } \\
\text { and plans exist. }\end{array}$ & $\begin{array}{l}\text { Global } \\
\text { Responsibility } \\
2015 \text { (p.48) }\end{array}$ \\
\hline 24 & $\begin{array}{l}\text { Does the company have } \\
\text { policies and plans for } \\
\text { sustainably sourcing of } \\
\text { commodities with a a } \\
\text { high environmental } \\
\text { footprint that are } \\
\text { relevant for its supply } \\
\text { chain? (eg, commodities } \\
\text { such as cocoa, coffee or } \\
\text { sugar)? }\end{array}$ & Yes/No & Yes & Yes/No & Yes & $\begin{array}{l}\text { Yes, policies } \\
\text { and plans exist. }\end{array}$ & $\begin{array}{l}\text { Global } \\
\text { Responsibility } \\
2015(p .43-50)\end{array}$ \\
\hline \multicolumn{3}{|c|}{2.3 Measurement and metrics } & & $E / M / F$ & Meets & & \\
\hline 25 & \begin{tabular}{|l|} 
What will the process be \\
for regularly measuring \\
and reporting on GHGs \\
in operations, supply \\
chain, and downstream \\
(scopes $1,2,3$ )? What \\
tools or models will be \\
used?
\end{tabular} & Detail & $\begin{array}{l}\text { Specific GHG measurement } \\
\text { techniques are mentioned for } \\
\text { dairy (pg. 56). General Mills } \\
\text { also follows the GRI framework } \\
\text { and reports to the CDP (pg. } 75- \\
\text { 77). The company follows the } \\
\text { US EPA Climate Leaders } \\
\text { methodology for Scope } 1 \text { and } 2 \\
\text { (CDP } 2015 \text { Climate Change } \\
\text { Response) Scope } 3 \text { emissions } \\
\text { are calculated using a } 2015 \\
\text { assessment by the LCA } \\
\text { consultancy Quantis. (CDP } \\
\text { 2015 Supply Chain Response) }\end{array}$ & $\mathrm{E} / \mathrm{M} / \mathrm{F}$ & Meets & \begin{tabular}{|l|} 
Both the \\
process for and \\
the tools used \\
for \\
measurement \\
are available.
\end{tabular} & $\begin{array}{l}\text { Global } \\
\text { Responsibility } \\
2015 \text { (p.56,75- } \\
77)\end{array}$ \\
\hline 26 & $\begin{array}{l}\text { Will supplier-level } \\
\text { agricultural emissions } \\
\text { be tracked directly (vs. } \\
\text { estimated from total } \\
\text { ingredient yields across } \\
\text { all suppliers of a given } \\
\text { ingredient)? Will the } \\
\text { company provide } \\
\text { tools/assistance to } \\
\text { suppliers to track their } \\
\text { GHGs? }\end{array}$ & Detail & \begin{tabular}{|l|} 
Specific GHG measurement \\
techniques are mentioned for \\
dairy (pg. 56). Other \\
measurement techniques are \\
mentioned for other crops (pg. \\
77 ), but it is not totally clear \\
how the measurements will be \\
taken or if tools will be provided.
\end{tabular} & $\mathrm{E} / \mathrm{M} / \mathrm{F}$ & Meets & $\begin{array}{l}\text { Supplier level } \\
\text { emissions } \\
\text { tracking is } \\
\text { sparsely } \\
\text { addressed and } \\
\text { more could be } \\
\text { provided on the } \\
\text { tools to be used } \\
\text { for tracking. }\end{array}$ & $\begin{array}{l}\text { Global } \\
\text { Responsibility } \\
2015(p .56,77)\end{array}$ \\
\hline 27 & $\begin{array}{l}\text { What Is the process for } \\
\text { assessing and reporting }\end{array}$ & Detail & $\begin{array}{l}\text { GRI and CDP are used for } \\
\text { Scope } 1 \text { and Scope } 2 \text {. Scope } 3\end{array}$ & $\mathrm{E} / \mathrm{M} / \mathrm{F}$ & Meets & $\begin{array}{l}\text { The process for } \\
\text { reporting and }\end{array}$ & $\begin{array}{l}\text { Global } \\
\text { Responsibility }\end{array}$ \\
\hline
\end{tabular}




\begin{tabular}{|c|c|c|c|c|c|c|c|}
\hline & $\begin{array}{l}\text { data on carbon } \\
\text { reductions, particularly } \\
\text { Scope } 3 ? \text { (e.g., is it } \\
\text { certified by a third-party } \\
\text { for data legitimacy?) } \\
\end{array}$ & & $\begin{array}{l}\text { emissions are reported as } \\
\text { percentages (pg. 77), but not in } \\
\text { the environmental data section } \\
\text { of the report. }\end{array}$ & & & $\begin{array}{l}\text { the third-parties } \\
\text { are identified. }\end{array}$ & 2015 (p.77) \\
\hline \multicolumn{4}{|c|}{2.4 Interim goals and target adjustments/flexibility } & $E / M / F$ & Meets & & \\
\hline 28 & $\begin{array}{l}\text { Are there targets in } \\
\text { place for interim years? }\end{array}$ & Yes/No & $\begin{array}{l}\text { As of the April } 2016 \text { Global } \\
\text { Responsibility Report, General } \\
\text { Mills has added a longer-term } \\
\text { target to "Reduce absolute } \\
\text { GHG emissions across our full } \\
\text { value chain to sustainable } \\
\text { levels in line with scientific } \\
\text { consensus" with a preliminary } \\
\text { range of } 41 \text { to } 72 \% \text {. In addition, } \\
\text { for } 10 \text { ingredients the company } \\
\text { has set targets to buy } 100 \% \\
\text { from sustainable sources by } \\
2020 \text {. }\end{array}$ & Yes/No & Yes & $\begin{array}{l}\text { With the } \\
\text { addition of the } \\
\text { long-term } \\
(2050) \text { target, } \\
\text { the original } \\
2025 \text { goal is } \\
\text { arguably now } \\
\text { an interim } \\
\text { target. The \% of } \\
\text { spend targets } \\
\text { for } 2020 \text {, issued } \\
\text { in } 2013, \text { are } \\
\text { also interim } \\
\text { targets, so long } \\
\text { as the definition } \\
\text { of "sustainably } \\
\text { source" includes } \\
\text { reductions of } \\
\text { GHGs in line } \\
\text { with the targets. }\end{array}$ & \begin{tabular}{|l} 
Global \\
Responsibility \\
2016 (p.34)
\end{tabular} \\
\hline 29 & $\begin{array}{l}\text { What are the interim } \\
\text { targets and for which } \\
\text { parts of the value } \\
\text { chain? }\end{array}$ & Detail & See above & $\mathrm{E} / \mathrm{M} / \mathrm{F}$ & Meets & $\begin{array}{l}\text { See above. } \\
\text { Whether the } \\
\text { "sustainably } \\
\text { sourced" } \\
\text { definition } \\
\text { includes explicit } \\
\text { GHG reductions } \\
\text { is unclear, but } \\
\text { the spirit of } \\
\text { interim targets is } \\
\text { in place. }\end{array}$ & $\begin{array}{l}\text { Global } \\
\text { Responsibility } \\
2016 \text { (p.40-58) }\end{array}$ \\
\hline 30 & $\begin{array}{l}\text { How will the company } \\
\text { incorporate the evolving } \\
\text { science on climate } \\
\text { change? }\end{array}$ & Detail & $\begin{array}{l}\text { General Mills is working with } \\
\text { BSR using a science based } \\
\text { methodology endorsed by } \\
\text { industry and other stakeholders. } \\
\text { The goal of this approach is to } \\
\text { cut emissions to keep } \\
\text { temperature rise below } 2 \text { C. } \\
\text { Goals will be updated every } 5 \\
\text { years to incorporate new } \\
\text { science. }\end{array}$ & $\mathrm{E} / \mathrm{M} / \mathrm{F}$ & Meets & $\begin{array}{l}\text { A plan to } \\
\text { recheck the } \\
\text { methodology } \\
\text { and latest } \\
\text { science every } 5 \\
\text { years is } \\
\text { sufficient for } \\
\text { now. }\end{array}$ & $\begin{array}{l}\text { Global } \\
\text { Responsibility } \\
2015 \text { (p.76) }\end{array}$ \\
\hline 31 & $\begin{array}{l}\text { Is there a process in } \\
\text { place to re-set or re- } \\
\text { establish the goals } \\
\text { before the target year if } \\
\text { necessary? }\end{array}$ & Detail & $\begin{array}{l}\text { "We will regularly review our } \\
\text { company statements and } \\
\text { policies to ensure they are } \\
\text { aligned with our mitigation } \\
\text { targets, plans and adaptation } \\
\text { initiatives. " }\end{array}$ & $\mathrm{E} / \mathrm{M} / \mathrm{F}$ & Meets & $\begin{array}{l}\text { This statement } \\
\text { does not } \\
\text { specifically } \\
\text { address the } \\
\text { question but } \\
\text { seems to be } \\
\text { close enough } \\
\text { and in the same } \\
\text { spirit of } \\
\text { transparency } \\
\text { and accuracy. }\end{array}$ & $\begin{array}{l}\text { Policy on } \\
\text { Climate }\end{array}$ \\
\hline
\end{tabular}




\begin{tabular}{|c|c|c|c|c|c|c|c|}
\hline \multicolumn{4}{|c|}{ 2.5 Transparency and communications } & \multirow{2}{*}{\begin{tabular}{|l|}
$E / M / F$ \\
$E / M / F$
\end{tabular}} & \multirow{2}{*}{\begin{tabular}{|l|} 
Meets \\
Meets \\
\end{tabular}} & \multirow[b]{2}{*}{$\begin{array}{l}\text { Yes the report } \\
\text { presents the } \\
\text { targets and } \\
\text { plans in a } \\
\text { transparent } \\
\text { manner. We } \\
\text { assume the new } \\
28 \% \text { target will } \\
\text { be included in } \\
\text { future reports. }\end{array}$} & \multirow[b]{2}{*}{\begin{tabular}{|l} 
Global \\
Responsibility \\
2015 (p.75)
\end{tabular}} \\
\hline 32 & $\begin{array}{l}\text { Is the information on } \\
\text { GHG reduction targets } \\
\text { and plans available } \\
\text { publicly in a transparent } \\
\text { and accessible manner? }\end{array}$ & Detail & $\begin{array}{l}\text { Yes, everything is in the } \\
\text { annual responsibility report }\end{array}$ & & & & \\
\hline 33 & $\begin{array}{l}\text { How will updates on } \\
\text { implementation } \\
\text { progress be shared? } \\
\text { How frequently? }\end{array}$ & Detail & $\begin{array}{l}\text { "Report progress against } \\
\text { goals - our own as well as } \\
\text { those in our broader supply } \\
\text { chain - on an annual basis } \\
\text { via our Global Responsibility } \\
\text { Report, available on the } \\
\text { General Mills website" }\end{array}$ & $\mathrm{E} / \mathrm{M} / \mathrm{F}$ & Meets & $\begin{array}{l}\text { The frequency } \\
\text { is specifically } \\
\text { stated in the } \\
\text { Climate Policy. } \\
\text { General Mills } \\
\text { also says it } \\
\text { shares pilot } \\
\text { results. }\end{array}$ & \begin{tabular}{|l|} 
Policy on \\
Climate, Global \\
Responsibility \\
2015 (p.42)
\end{tabular} \\
\hline
\end{tabular}




\begin{tabular}{|c|c|c|c|c|c|c|c|}
\hline \multicolumn{2}{|c|}{$\begin{array}{l}\text { 1. ROBUSTNESS OF } \\
\text { TARGET SETTING }\end{array}$} & $\begin{array}{l}\text { Data } \\
\text { Format }\end{array}$ & $\begin{array}{l}\text { KELLOGG'S } \\
\text { RESPONSE }\end{array}$ & $\begin{array}{l}\text { Scorin } \\
\text { g } \\
\text { Rubric }\end{array}$ & $\begin{array}{l}\text { Assess } \\
\text { ment }\end{array}$ & $\begin{array}{l}\text { Reasoning/Clarifica } \\
\text { tions }\end{array}$ & $\begin{array}{l}\text { Source } \\
\text { (public } \\
\text { information) }\end{array}$ \\
\hline \multicolumn{3}{|c|}{$\begin{array}{l}1.1 \text { Base information on the } \\
\text { target and inclusion of scope } 3 \\
\text { (primarily agricultural } \\
\text { emissions) }\end{array}$} & & $E / M / F$ & Meets & & \\
\hline 1 & $\begin{array}{l}\text { What is the target } \\
\text { GHG reduction? }\end{array}$ & $\%$ & $\begin{array}{l}65 \text { percent across its } \\
\text { own operations, } \\
\text { known as Scope } 1 \\
\text { and } 2 \text {, and reduction } \\
\text { in supplier } \\
\text { emissions, known as } \\
\text { Scope } 3 \text {, of } 50 \\
\text { percent by } 2050 \text {; } \\
\text { shorter-term targets } \\
\text { as well of } 15 \% \\
\text { (normalized) in own } \\
\text { operations by } 2020 \\
\text { and Scope } 3 \text { cut of } \\
20 \% \text { by } 2030 \text {. }\end{array}$ & Yes/No & Yes & Yes, target is set & $\begin{array}{l}\text { Company } \\
\text { press } \\
\text { release, } \\
\text { "Kellogg } \\
\text { Company } \\
\text { Announce } \\
\text { s New..." }\end{array}$ \\
\hline 2 & $\begin{array}{l}\text { Is the target for } \\
\text { absolute } \\
\text { emissions (vs. } \\
\text { relative/intensity)? }\end{array}$ & Yes/No & $\begin{array}{l}2050 \text { targets are } \\
\text { absolute, } 2020 \text { cut of } \\
15 \% \text { in own } \\
\text { operations is } \\
\text { normalized. }\end{array}$ & Yes/No & Yes & $\begin{array}{l}\text { Long-term goal is } \\
\text { absolute }\end{array}$ & $\begin{array}{l}\text { Climate } \\
\text { Policy } \\
\text { Context } \\
\text { and } \\
\text { Methodolo } \\
\text { gy (p.8) }\end{array}$ \\
\hline 3 & $\begin{array}{l}\text { What is the } \\
\text { timeline of the } \\
\text { target? Baseline? } \\
\text { Starting when and } \\
\text { by when? }\end{array}$ & Years & $\begin{array}{l}\text { Due: } 2050 ; \text { baseline } \\
\text { not provided } \\
\text { specifically }\end{array}$ & Yes/No & Yes & $\begin{array}{l}\text { The goals were } \\
\text { originally set in } \\
\text { August } 2014 \text { but that } \\
\text { does not necessarily } \\
\text { equate to a baseline } \\
\text { year. }\end{array}$ & $\begin{array}{l}\text { Company } \\
\text { press } \\
\text { release, } \\
\text { "Kellogg } \\
\text { Company } \\
\text { Announce } \\
\text { s New..." }\end{array}$ \\
\hline 4 & $\begin{array}{l}\text { What parts of } \\
\text { value chain are } \\
\text { included in the } \\
\text { target? Are scope } \\
3 \text { and/or } \\
\text { agricultural } \\
\text { emissions } \\
\text { included? }\end{array}$ & $\begin{array}{l}\text { Details; } \\
\text { Yes/No }\end{array}$ & $\begin{array}{l}\text { Operations and } \\
\text { Suppliers }\end{array}$ & Yes/No & Yes & $\begin{array}{l}\text { Two specific value } \\
\text { chain stages are } \\
\text { included }\end{array}$ & $\begin{array}{l}\text { Company } \\
\text { press } \\
\text { release, } \\
\text { "Kellogg } \\
\text { Company } \\
\text { Announce } \\
\text { s New..." }\end{array}$ \\
\hline 5 & $\begin{array}{l}\text { How is the target } \\
\text { divided amongst } \\
\text { value chain parts } \\
\text { (all the same } \\
\text { target or } \\
\text { variable)? }\end{array}$ & Details & $\begin{array}{l}65 \% \text { reduction in } \\
\text { their own operations; } \\
50 \% \text { for the supply } \\
\text { chain }\end{array}$ & $\mathrm{E} / \mathrm{M} / \mathrm{F}$ & Meets & $\begin{array}{l}\text { Two specific } \\
\text { percentages are } \\
\text { presented }\end{array}$ & $\begin{array}{l}\text { Company } \\
\text { press } \\
\text { release, } \\
\text { "Kellogg } \\
\text { Company } \\
\text { Announce } \\
\text { s New..." }\end{array}$ \\
\hline \multicolumn{2}{|c|}{$\begin{array}{l}\text { 1.2 Strength of data } \\
\text { behind targets }\end{array}$} & & & $E / M / F$ & Meets & & \\
\hline 6 & $\begin{array}{l}\text { Does the } \\
\text { company have } \\
\text { GHG emission } \\
\text { data with } \\
\text { percentages } \\
\text { broken down by } \\
\text { scope and/or } \\
\text { value chain stage } \\
\text { (e.g. } 70 \% \text { supply } \\
\text { chain; } 25 \% \\
\text { operations; } 5 \% \\
\text { EOL) }\end{array}$ & $\begin{array}{l}\text { \% with } \\
\text { detail }\end{array}$ & $\begin{array}{l}\text { "Carbon Calculation } \\
\text { and Forecasting } \\
\text { Tool is an Excel } \\
\text { model built to } \\
\text { aggregate and } \\
\text { project...carbon } \\
\text { emissions...across } \\
\text { the value chain" } \\
\text { AND vs. industry } \\
\text { benchmarking, "this } \\
\text { analysis [estimates] } \\
\text { that ingredients are } \\
\text { fewer than } 50 \% \text { of }\end{array}$ & $\mathrm{E} / \mathrm{M} / \mathrm{F}$ & Meets & $\begin{array}{l}\text { While the estimation } \\
\text { process is not } \\
\text { completely clear -- } \\
\text { nor whether there } \\
\text { are numbers for all } \\
\text { value chain stages -- } \\
\text { Kellogg's seems to } \\
\text { have a solid } \\
\text { estimate of the } \\
\text { portion of lifecycle } \\
\text { emissions upstream } \\
\text { in agriculture. That } \\
\text { said, in order to track }\end{array}$ & $\begin{array}{l}\text { Climate } \\
\text { Policy } \\
\text { Context } \\
\text { and } \\
\text { Methodolo } \\
\text { gy (p.2-3) }\end{array}$ \\
\hline
\end{tabular}




\begin{tabular}{|c|c|c|c|c|c|c|c|}
\hline & & & $\begin{array}{l}\text { total carbon } \\
\text { emitted." }\end{array}$ & & & $\begin{array}{l}\text { progress on these } \\
\text { targets, the numbers } \\
\text { may need to get } \\
\text { more specific. }\end{array}$ & \\
\hline 7 & $\begin{array}{l}\text { How is data on } \\
\text { agricultural } \\
\text { emissions } \\
\text { reported and } \\
\text { analyzed? (e.g., } \\
\text { Does the } \\
\text { company have } \\
\text { data on } \\
\text { agricultural } \\
\text { emissions, Is the } \\
\text { data aggregated } \\
\text { or broken down } \\
\text { by } \\
\text { ingredient/commo } \\
\text { dity or by category } \\
\text { (dairy vs. row } \\
\text { crops)?) }\end{array}$ & $\begin{array}{l}\text { \% with } \\
\text { detail }\end{array}$ & $\begin{array}{l}\text { From the CDP } \\
\text { report: "we have } \\
\text { calculated estimated } \\
\text { emissions for our } \\
\text { primary ingredients - } \\
\text { corn, wheat, rice, } \\
\text { palm oil, and } \\
\text { potatoes - based on } \\
\text { established GHG } \\
\text { emission factors for } \\
\text { various agricultural } \\
\text { inputs." }\end{array}$ & $\mathrm{E} / \mathrm{M} / \mathrm{F}$ & Meets & $\begin{array}{l}\text { The input volumes, } \\
\text { and emissions } \\
\text { data/calculations by } \\
\text { key ingredient are } \\
\text { provided in the } \\
\text { company's CDP } \\
\text { Report. }\end{array}$ & $\begin{array}{l}\text { Kellogg } \\
\text { Company } \\
2015 \text { CDP } \\
\text { Carbon } \\
\text { report }\end{array}$ \\
\hline 8 & $\begin{array}{l}\text { How are } \\
\text { agricultural } \\
\text { emissions data } \\
\text { calculated? (e.g., } \\
\text { actual yield } \\
\text { combined with } \\
\text { emissions } \\
\text { estimated from } \\
\text { academic studies } \\
\text { of specific crops)? }\end{array}$ & Detail & $\begin{array}{l}\text { "Baseline will be set } \\
\text { for Scope } 3 \\
\text { emissions from Tier } \\
1 \text { suppliers...based } \\
\text { off actual reported } \\
\text { yields...combined } \\
\text { with emission } \\
\text { estimates from } \\
\text { academic studies for } \\
\text { that crop...farmer } \\
\text { measurement tools } \\
\text { like Cool Farm } \\
\text { Tool...to capture } \\
\text { specific emissions } \\
\text { from rice production, } \\
\text { nitrogen fertilizer } \\
\text { application and on- } \\
\text { farm energy use" }\end{array}$ & $\mathrm{E} / \mathrm{M} / \mathrm{F}$ & Meets & $\begin{array}{l}\text { Kellogg provides a } \\
\text { clear statement of } \\
\text { how the emissions } \\
\text { will be calculated for } \\
\text { some crops and the } \\
\text { tools used. Over } \\
\text { time, it appears that } \\
\text { tools will enable } \\
\text { farm-level data, } \\
\text { which would warrant } \\
\text { an 'exceeds' rating. }\end{array}$ & $\begin{array}{l}\text { Climate } \\
\text { Policy } \\
\text { Context } \\
\text { and } \\
\text { Methodolo } \\
\text { gy (p.9) }\end{array}$ \\
\hline 9 & $\begin{array}{l}\text { What is the quality } \\
\text { of company's } \\
\text { GHG data, } \\
\text { including } \\
\text { agricultural } \\
\text { emissions data } \\
\text { (e.g., What is } \\
\text { baseline year of } \\
\text { solid data for } \\
\text { GHGs?, Is data } \\
\text { third-party } \\
\text { verified?) }\end{array}$ & Detail & $\begin{array}{l}\text { The model estimates } \\
\text { emissions going } \\
\text { back to } 2009\end{array}$ & $\mathrm{E} / \mathrm{M} / \mathrm{F}$ & Meets & $\begin{array}{l}\text { Estimation is } \\
\text { backdated to } 2009 \text {, } \\
\text { giving Kellogg's a } \\
\text { baseline, but see } \\
\text { line } 6 \text { for same } \\
\text { caveat about data } \\
\text { specificity }\end{array}$ & $\begin{array}{l}\text { Climate } \\
\text { Policy } \\
\text { Context } \\
\text { and } \\
\text { Methodolo } \\
\text { gy (p.2-3) }\end{array}$ \\
\hline
\end{tabular}




\begin{tabular}{|c|c|c|c|c|c|c|c|}
\hline \multicolumn{3}{|c|}{$\begin{array}{l}\text { 1.3 Strength/quality of target on } \\
\text { agricultural emissions } \\
\text { specifically }\end{array}$} & 2 & \multirow{2}{*}{$\begin{array}{l}E / M / F \\
\\
E / M / F\end{array}$} & \multirow{2}{*}{$\begin{array}{l}\text { Meets }^{*} \\
\text { Meets }^{*}\end{array}$} & \multirow[b]{2}{*}{$\begin{array}{l} \\
\text { There is } \\
\text { transparency about } \\
\text { what portion of } \\
\text { Kellogg supplier } \\
\text { base is covered. } \\
\text { While } 85 \% \text { of spend } \\
\text { (and } 80 \% \text { of } \\
\text { suppliers, a number } \\
\text { provided directly by } \\
\text { the company) is } \\
\text { clear, the target } \\
\text { does not cover } \\
100 \% \text { of supply } \\
\text { chain emissions. } \\
\text { Over time, the } \\
\text { longer-term plan for } \\
\text { these targets, and } \\
\text { the execution plans, } \\
\text { must move toward } \\
100 \% \text { of suppliers, } \\
\text { or the targets will } \\
\text { need to be adjusted } \\
\text { to reflect the } \\
\text { incomplete } \\
\text { coverage. }\end{array}$} & \multirow{2}{*}{$\begin{array}{l} \\
\\
\text { Company } \\
\text { press } \\
\text { release, } \\
\text { "Kellogg } \\
\text { Company } \\
\text { Announce } \\
\text { s New..." } \\
\text { \& Kellogg } \\
\text { CDP 2015 } \\
\text { report }\end{array}$} \\
\hline 10 & $\begin{array}{l}\text { What percentage } \\
\text { of agricultural } \\
\text { ingredients is } \\
\text { included in the } \\
\text { target (By } \\
\text { volume of } \\
\text { ingredients? By } \\
\text { CO2e of ag } \\
\text { emissions?) }\end{array}$ & $\%$ & $\begin{array}{l}\text { "75 percent of the } \\
\text { company's direct } \\
\text { suppliers will report } \\
\text { progress annually } \\
\text { through CDP } \\
\text { Supply Chain by } \\
2020 . " \text { and } \\
\text { "requiring all key } \\
\text { suppliers to } \\
\text { measure and } \\
\text { publicly disclose } \\
\text { their own } \\
\text { emissions and } \\
\text { reduction targets" } \\
\text { Percent of total } \\
\text { spend is indicated } \\
\text { in the CDP report } \\
\text { as } 85 \% \text {. }\end{array}$ & & & & \\
\hline 11 & $\begin{array}{l}\text { What sources of } \\
\text { agricultural } \\
\text { emissions are } \\
\text { included in the } \\
\text { target? (See list } \\
\text { below for major } \\
\text { sources) }\end{array}$ & Detail & $\begin{array}{l}\text { Kellogg's } \\
\text { documents cite } \\
\text { work on } \\
\text { deforestation, rice } \\
\text { production, and } \\
\text { fertilizer } \\
\text { optimization, } \\
\text { particularly for the } \\
10 \text { priority } \\
\text { ingredients in the } \\
\text { sustainable } \\
\text { sourcing policy. }\end{array}$ & $\mathrm{E} / \mathrm{M} / \mathrm{F}$ & Meets & $\begin{array}{l}\text { Most major sources } \\
\text { are referenced in the } \\
\text { policy documents. } \\
\text { Kellogg's has limited } \\
\text { exposure to some of } \\
\text { these sources such } \\
\text { as livestock } \\
\text { emissions. }\end{array}$ & $\begin{array}{l}\text { Responsib } \\
\text { le } \\
\text { Sourcing } \\
\text { (p.18, 22- } \\
\text { 4), Climate } \\
\text { Policy } \\
\text { Context } \\
\text { and } \\
\text { Methodolo } \\
\text { gy (p.2) }\end{array}$ \\
\hline & $\begin{array}{l}\text { a. Deforestation ar } \\
\text { management) c. } R \\
\text { f. on farm energy } u\end{array}$ & ario & $\begin{array}{l}\text { Ise change b. livesto } \\
\text { d. nitrogen fertilizer } \\
\text { stream fertilizer prod }\end{array}$ & $\begin{array}{l}\text { oplicati } \\
\text { tion, h. }\end{array}$ & $\begin{array}{l}\text { oth syn } \\
\text { r as ap }\end{array}$ & $\begin{array}{l}\text { fermentation and ma } \\
\text { and manure); e. pea } \\
\text { le }\end{array}$ & d drainage; \\
\hline 12 & $\begin{array}{l}\text { How is food } \\
\text { waste --i.e., } \\
\text { losses on-farm or } \\
\text { between farm } \\
\text { and } \\
\text { manufacturing -- } \\
\text { accounted for? } \\
\text { (i.e., is all farm } \\
\text { production } \\
\text { included or just } \\
\text { emissions related } \\
\text { to inputs that are } \\
\text { utilized) }\end{array}$ & Detail & $\begin{array}{l}\text { Policy paper } \\
\text { mentions looking } \\
\text { forward to sector- } \\
\text { based and industry } \\
\text { work on scope } 3 \text {, } \\
\text { "including from } \\
\text { food waste". Also } \\
\text { mention of tools } \\
\text { like Cool Farm and } \\
\text { WRI Food Waste } \\
\text { and Loss Standard }\end{array}$ & $\mathrm{E} / \mathrm{M} / \mathrm{F}$ & Meets & $\begin{array}{l}\text { Utilizing a leading } \\
\text { third-party tool will } \\
\text { likely account for } \\
\text { some dimensions of } \\
\text { food waste, but this } \\
\text { would need to be } \\
\text { investigated further }\end{array}$ & $\begin{array}{l}\text { Climate } \\
\text { Policy } \\
\text { Context } \\
\text { and } \\
\text { Methodolo } \\
\text { gy (p.2) }\end{array}$ \\
\hline
\end{tabular}




\begin{tabular}{|c|c|c|c|c|c|c|c|}
\hline \multicolumn{4}{|c|}{$\begin{array}{l}1.4 \text { Consistency with } 2 C \text { science-based methodology } \\
\text { and thresholds }\end{array}$} & \multirow{2}{*}{$\begin{array}{l}E / M / F \\
\\
E / M / F\end{array}$} & \multirow{2}{*}{$\begin{array}{l}\text { Meets }^{\star *} \\
\text { Meets }^{\star *}\end{array}$} & \multirow[b]{2}{*}{$\begin{array}{l}\text { } \\
\text { Kellogg's utilized all } \\
\text { major methods of } \\
\text { setting science- } \\
\text { based targets (WRI, } \\
\text { WWF, and } \\
\text { underlying IPCC } \\
\text { data) and these are } \\
\text { generally accepted } \\
\text { as sufficient for } \\
\text { setting SBTs. } \\
\text { CAVEATS: (1) The } \\
\text { Global policy } \\
\text { community has } \\
\text { included discussion } \\
\text { of a } 1.5 \text { degree } \\
\text { warming scenario } \\
\text { now, and this goal is } \\
\text { targeting the } 2- \\
\text { degree scenario. (2) } \\
\text { Neither the } 3 \% \\
\text { solution nor SDA } \\
\text { have (yet) calculated } \\
\text { an agriculture sector } \\
\text { target; thus it is } \\
\text { uncertain if the } 2050 \\
\text { target for supply } \\
\text { chain will fit that } \\
\text { methodology (but as } \\
\text { Kellogg's notes, its } \\
2015 \text { baseline is } \\
\text { more aggressive } \\
\text { than the } 2010 \text { IPCC } \\
\text { starting point). We } \\
\text { look then to the } \\
\text { company's intended } \\
\text { process for staying } \\
\text { up to date (lines } 30- \\
31 \text { ) }\end{array}$} & \multirow{2}{*}{$\begin{array}{l} \\
\\
\text { Climate } \\
\text { Policy } \\
\text { Context } \\
\text { and } \\
\text { Methodolo } \\
\text { gy (p.2,4- } \\
\text { 6) }\end{array}$} \\
\hline 13 & $\begin{array}{l}\text { What was the } \\
\text { target setting } \\
\text { process and } \\
\text { what, if any, } \\
\text { science based } \\
\text { methodologies } \\
\text { were utilized? } \\
\text { (e.g., does the } \\
\text { target align with } \\
\text { carbon budget } \\
\text { estimations from } \\
\text { IPCC, was the } \\
\text { target derived } \\
\text { through straight- } \\
\text { line reductions or } \\
\text { sector-based } \\
\text { methodologies } \\
\text { etc?) }\end{array}$ & Details & $\begin{array}{l}\text { "Kellogg used the } \\
\text { IPCC framework } \\
\text { and data to } \\
\text { establish a starting } \\
\text { point for science- } \\
\text { based reductions. } \\
\text { The result of this } \\
\text { assessment was } \\
\text { then tested through } \\
\text { two } \\
\text { additional tools } \\
\text { created by trusted } \\
\text { third parties: } \\
\text { Sectoral } \\
\text { Decarbonization } \\
\text { Approach [WRI] } \\
\text { and the 3\% } \\
\text { Solution [WWF]." }\end{array}$ & & & & \\
\hline
\end{tabular}

\begin{tabular}{|c|c|c|c|c|c|c|}
\hline \multicolumn{3}{|c|}{$\begin{array}{l}1.5 \text { Consistency with best } \\
\text { practice }\end{array}$} & \multirow{2}{*}{$\begin{array}{l}E / M / F \\
E / M / F\end{array}$} & \multirow{2}{*}{$\begin{array}{l}\text { Exceeds } \\
\text { Exceeds }\end{array}$} & \multirow[b]{2}{*}{$\begin{array}{l} \\
\text { The target is leading } \\
\text { in the ag sector and } \\
\text { in keeping with best } \\
\text { practice across other } \\
\text { sectors that have set } \\
\text { aggressive targets, } \\
\text { especially with the } \\
\text { inclusion of } 2050 \\
\text { goals. Kellogg has } \\
\text { already delivered } \\
12 \% \text { reduction in } \\
\text { manufacturing. The } \\
\text { additional scope } 1 \\
\text { and } 2 \text { target of } 15 \% \\
\text { (normalized) for } \\
2020 \text { and the } 50 \% \\
\text { low-carbon energy } \\
\text { targets are strong. } \\
\text { While some large } \\
\text { companies have } \\
\text { gone further to target } \\
100 \% \text { renewable or }\end{array}$} & \multirow{2}{*}{$\begin{array}{l} \\
\text { PivotGoals } \\
\text { database } \\
\text { and WES } \\
\text { analysis }\end{array}$} \\
\hline 14 & $\begin{array}{l}\text { How does the } \\
\text { target compare } \\
\text { to the most } \\
\text { aggressive } \\
\text { SBTs from the } \\
\text { Global Fortune } \\
500 \text { or other } \\
\text { best practice } \\
\text { examples (eg } \\
\text { goals on } \\
\text { renewable } \\
\text { energy, waste } \\
\text { reduction, } \\
\text { deforestation } \\
\text { etc) }\end{array}$ & NA - WES analysis & & & & \\
\hline
\end{tabular}




\begin{tabular}{|c|c|c|c|c|c|c|c|}
\hline & & & & & & $\begin{array}{l}\text { net positive on } \\
\text { carbon, the inclusion } \\
\text { here of supply chain } \\
\text { emissions in } \\
\text { science-based } \\
\text { targets is currently } \\
\text { rare. }\end{array}$ & \\
\hline \multicolumn{2}{|c|}{$\begin{array}{l}\text { 2. PLAN TO REACH } \\
\text { THE } \\
\text { GOALS/TARGETS }\end{array}$} & $\begin{array}{l}\text { Data } \\
\text { Format }\end{array}$ & $\begin{array}{l}\text { Kellogg's } \\
\text { Response }\end{array}$ & $\begin{array}{l}\text { Asses } \\
\text { sment }\end{array}$ & $\begin{array}{l}\text { Scoring } \\
\text { Rubric }\end{array}$ & $\begin{array}{l}\text { Reasoning/Clarifica } \\
\text { tions }\end{array}$ & Source \\
\hline \multicolumn{3}{|c|}{ 2.1 Governance/Accountability } & & $E / M / F$ & Meets & & \\
\hline 15 & $\begin{array}{l}\text { Who in the } \\
\text { organization is } \\
\text { responsible for } \\
\text { meeting GHG } \\
\text { targets? And for } \\
\text { measuring/estim } \\
\text { ating agricultural } \\
\text { emissions? }\end{array}$ & Detail & $\begin{array}{l}\text { Five executives } \\
\text { and the Chief } \\
\text { Sustainability } \\
\text { Officer. The five } \\
\text { executives are not } \\
\text { specified. }\end{array}$ & $\mathrm{E} / \mathrm{M} / \mathrm{F}$ & Meets & $\begin{array}{l}\text { This meets and } \\
\text { arguably exceeds } \\
\text { expectations }\end{array}$ & $\begin{array}{l}\text { Corporate } \\
\text { Responsib } \\
\text { ility Report } \\
\text { (p.9) }\end{array}$ \\
\hline 16 & $\begin{array}{l}\text { Is there CEO or } \\
\text { Board oversight } \\
\text { on carbon } \\
\text { targets? }\end{array}$ & Yes/No & Yes & Yes/No & Yes & $\begin{array}{l}\text { The five executives } \\
\text { are not specified but } \\
\text { this setup seems to } \\
\text { meet the spirit of the } \\
\text { requirement. }\end{array}$ & $\begin{array}{l}\text { Corporate } \\
\text { Responsib } \\
\text { ility Report } \\
\text { (p.9) }\end{array}$ \\
\hline 17 & $\begin{array}{l}\text { Are there } \\
\text { incentives in } \\
\text { place for } \\
\text { company } \\
\text { managers, or for } \\
\text { suppliers, to } \\
\text { meet GHG } \\
\text { targets? }\end{array}$ & Detail & $\begin{array}{l}\text { Kellogg states that } \\
\text { "Sustainability } \\
\text { commitments } \\
\text { focused on GHG } \\
\text { targets, including } \\
\text { supply chain } \\
\text { engagement and } \\
\text { the Kellogg Grower } \\
\text { Survey, are } \\
\text { included in } \\
\text { performance } \\
\text { development plans } \\
\text { (PDPs) and goals } \\
\text { for cross functional } \\
\text { teams and } \\
\text { leadership, } \\
\text { including } \\
\text { procurement and } \\
\text { sustainability. } \\
\text { Performance } \\
\text { against PDP } \\
\text { contributes to } \\
\text { Annual Incentive } \\
\text { Plans for these } \\
\text { individuals...Suppli } \\
\text { er performance is } \\
\text { also annually } \\
\text { measured, where } \\
\text { responsible } \\
\text { sourcing (including } \\
\text { participation and } \\
\text { disclosure level for } \\
\text { CDP supply chain) } \\
\text { is measured } \\
\text { equality to other } \\
\text { business drivers } \\
\text { like on-time and in- } \\
\text { full delivery. }\end{array}$ & $\mathrm{E} / \mathrm{M} / \mathrm{F}$ & Meets & $\begin{array}{l}\text { The incentives for } \\
\text { managers and } \\
\text { suppliers meets } \\
\text { expectations. }\end{array}$ & $\begin{array}{l}\text { Kellogg } \\
\text { Company } \\
2015 \text { CDP } \\
\text { Carbon } \\
\text { report, } \\
\text { Company } \\
\text { response } \\
\text { to this } \\
\text { assessme } \\
\text { nt }\end{array}$ \\
\hline \multicolumn{3}{|c|}{2.2 Supplier engagement plans } & & $E / M / F$ & Meets & & \\
\hline
\end{tabular}




\begin{tabular}{|c|c|c|c|c|c|c|c|}
\hline \multicolumn{8}{|c|}{ for GHG reductions } \\
\hline 18 & $\begin{array}{l}\text { How will the } \\
\text { company require } \\
\text { suppliers to } \\
\text { measurably } \\
\text { reduce } \\
\text { agricultural } \\
\text { emissions (e.g., } \\
\text { what } \\
\text { mechanisms } \\
\text { such as supplier } \\
\text { codes will be } \\
\text { used)? }\end{array}$ & Detail & $\begin{array}{l}\text { In Responsible } \\
\text { Sourcing: } \\
\text { "Suppliers must } \\
\text { strive to reduce or } \\
\text { optimize } \\
\text { agricultural inputs; } \\
\text { reduce GHG } \\
\text { emissions..." and } \\
\text { Kellogg's asks } \\
\text { them to do so in } \\
\text { the supplier code. }\end{array}$ & $\mathrm{E} / \mathrm{M} / \mathrm{F}$ & Meets & $\begin{array}{l}\text { The responsible } \\
\text { sourcing document, } \\
\text { the CDP report on } \\
\text { engagement } \\
\text { (CC14.4a), and } \\
\text { additional } \\
\text { documents } \\
\text { demonstrate that the } \\
\text { company is having } \\
\text { consistent } \\
\text { conversations with } \\
\text { suppliers about } \\
\text { reducing their } \\
\text { emissions. How } \\
\text { requirements will be } \\
\text { implemented is not } \\
\text { entirely unclear, but } \\
\text { the program seems } \\
\text { robust. }\end{array}$ & $\begin{array}{l}\text { Responsib } \\
\text { le } \\
\text { Sourcing } \\
\text { (p.18), } \\
\text { Kellogg } \\
\text { Inputs } \\
\text { Excel } \\
\text { Sheet }\end{array}$ \\
\hline 19 & $\begin{array}{l}\text { How will the } \\
\text { company assess } \\
\text { pathways to } \\
\text { reductions and } \\
\text { opportunities to } \\
\text { embed new } \\
\text { sustainable } \\
\text { agricultural } \\
\text { practices and } \\
\text { techniques? } \\
\text { What external } \\
\text { experts or } \\
\text { partners, if any, } \\
\text { will be } \\
\text { consulted? }\end{array}$ & Detail & $\begin{array}{l}\text { Kellogg's provides } \\
\text { research and } \\
\text { education to } \\
\text { suppliers so they } \\
\text { can embed the } \\
\text { practices in their } \\
\text { work. Kellogg's } \\
\text { also partners with } \\
\text { the Cool Farm } \\
\text { Institute, which } \\
\text { provides farmers } \\
\text { with a way to } \\
\text { calculate GHG } \\
\text { emissions at the } \\
\text { farm level. Also } \\
\text { work with Climate } \\
\text { Smart Agriculture, } \\
\text { Field to Market } \\
\text { (Fieldprint } \\
\text { calculator), SAI, } \\
\text { Cool Farm } \\
\text { Alliance, AIM- } \\
\text { Progress, WWF, } \\
\text { TNC, and others. }\end{array}$ & $\mathrm{E} / \mathrm{M} / \mathrm{F}$ & Meets & $\begin{array}{l}\text { A process exists and } \\
\text { experts and partners } \\
\text { consulted are } \\
\text { specified. }\end{array}$ & $\begin{array}{l}\text { Climate } \\
\text { Policy } \\
\text { Context } \\
\text { and } \\
\text { Methodolo } \\
\text { gy (p.9), } \\
\text { Responsib } \\
\text { le } \\
\text { Sourcing } \\
\text { (p.17, 24) }\end{array}$ \\
\hline 20 & $\begin{array}{l}\text { How will the } \\
\text { company provide } \\
\text { suppliers best } \\
\text { practices on key } \\
\text { sustainable } \\
\text { agricultural } \\
\text { techniques (e.g., } \\
\text { no-tillage, cover } \\
\text { crops, rotation, } \\
\text { nutrient } \\
\text { management, } \\
\text { manure } \\
\text { management)? }\end{array}$ & Detail & $\begin{array}{l}\text { Kellogg's works } \\
\text { with various } \\
\text { suppliers on a crop } \\
\text { by crop basis and } \\
\text { developed a 4-level } \\
\text { certification } \\
\text { program. There are } \\
\text { some best practice } \\
\text { sharing } \\
\text { opportunities in } \\
\text { "grower days". In } \\
\text { addition, Kellogg is } \\
\text { one of the } \\
\text { members of the } \\
\text { WBCSD Low } \\
\text { Carbon } \\
\text { Technology } \\
\text { Partnerships } \\
\text { Initiative }\end{array}$ & $\mathrm{E} / \mathrm{M} / \mathrm{F}$ & Meets & $\begin{array}{l}\text { The company's } \\
\text { multiple programs } \\
\text { provide significant } \\
\text { evidence of projects } \\
\text { to gather and share } \\
\text { best practice }\end{array}$ & $\begin{array}{l}\text { Responsib } \\
\text { le } \\
\text { Sourcing } \\
\text { (p.18, 23), } \\
\text { WBCSD } \\
\text { partnershi } \\
\text { p }\end{array}$ \\
\hline
\end{tabular}




\begin{tabular}{|c|c|c|c|c|c|c|c|}
\hline 21 & $\begin{array}{l}\text { Will the company } \\
\text { aid suppliers on } \\
\text { implementing } \\
\text { new technologies } \\
\text { and techniques } \\
\text { directly (e.g., with } \\
\text { human or } \\
\text { financial capital?) }\end{array}$ & Detail & $\begin{array}{l}\text { Kellogg's works } \\
\text { with various } \\
\text { suppliers and other } \\
\text { partners on a crop } \\
\text { by crop basis, } \\
\text { including rice, corn, } \\
\text { wheat, and sugar } \\
\text { beet. Responsible } \\
\text { sourcing policy } \\
\text { also mentions } \\
\text { "direct investment } \\
\text { in programs on the } \\
\text { ground" as does } \\
\text { the company's } \\
2020 \text { goals } \\
\text { statement, with } \\
\text { specific crops } \\
\text { identified for direct } \\
\text { investment. } \\
\text { Additional } \\
\text { information from } \\
\text { the company } \\
\text { indicates over } 30 \\
\text { direct investment } \\
\text { projects. }\end{array}$ & $\mathrm{E} / \mathrm{M} / \mathrm{F}$ & Meets & $\begin{array}{l}\text { The amount of } \\
\text { investment allocated } \\
\text { to helping suppliers } \\
\text { is unclear, but it is } \\
\text { publicly stated that } \\
\text { the company will } \\
\text { provide direct } \\
\text { investment and } \\
\text { support which } \\
\text { strongly implies } \\
\text { human and financial } \\
\text { support. }\end{array}$ & $\begin{array}{l}\text { Responsib } \\
\text { le } \\
\text { Sourcing } \\
\text { (p.18, 23- } \\
25) ; \\
\text { Kellogg } \\
\text { Sustainabil } \\
\text { ity } 2020 \\
\text { Commitme } \\
\text { nts }\end{array}$ \\
\hline 22 & $\begin{array}{l}\text { How will the } \\
\text { progress of } \\
\text { operational } \\
\text { changes in the } \\
\text { supply chain be } \\
\text { tracked? }\end{array}$ & Detail & $\begin{array}{l}\text { Kellogg's is using a } \\
\text { range of tools to } \\
\text { assess impacts } \\
\text { and progress, } \\
\text { including Field to } \\
\text { Market@, the } \\
\text { Kellogg Grower } \\
\text { Survey, Cool Farm } \\
\text { Tool, and other } \\
\text { industry accepted } \\
\text { farm management } \\
\text { tools. }\end{array}$ & $\mathrm{E} / \mathrm{M} / \mathrm{F}$ & Meets & $\begin{array}{l}\text { The company is } \\
\text { using numerous } \\
\text { tools and has } \\
\text { provided data on } \\
\text { how prevalent the } \\
\text { use of these tools is. }\end{array}$ & $\begin{array}{l}\text { Responsib } \\
\text { le } \\
\text { Sourcing } \\
\text { (p.18) }\end{array}$ \\
\hline 23 & $\begin{array}{l}\text { Does the } \\
\text { company have } \\
\text { policies and } \\
\text { plans for } \\
\text { achieving zero } \\
\text { deforestation } \\
\text { across all high } \\
\text { forest risk } \\
\text { commodities it } \\
\text { sources? }\end{array}$ & Yes/No & $\begin{array}{l}\text { Kellogg's is } \\
\text { committed to zero } \\
\text { net deforestation } \\
\text { by } 2020 \text {. They are } \\
\text { also not buying soy } \\
\text { products from } \\
\text { deforested region } \\
\text { and their palm oil } \\
\text { strategy has been } \\
\text { informed by this } \\
\text { commitment. Also, } \\
\text { they are a } \\
\text { members of the } \\
\text { Consumer Goods } \\
\text { Forum } \\
\text { commitments. }\end{array}$ & Yes/No & Yes & $\begin{array}{l}\text { They have a policy } \\
\text { in place with a near } \\
\text { term zero target, } \\
\text { projects in place, } \\
\text { and participation in a } \\
\text { group member } \\
\text { forum. This arguably } \\
\text { exceeds } \\
\text { expectations. }\end{array}$ & $\begin{array}{l}\text { Responsib } \\
\text { le } \\
\text { Sourcing } \\
\text { (p.25) }\end{array}$ \\
\hline 24 & $\begin{array}{l}\text { Does the } \\
\text { company have } \\
\text { policies and } \\
\text { plans for } \\
\text { sustainably } \\
\text { sourcing of } \\
\text { commodities with } \\
\text { a a high } \\
\text { environmental } \\
\text { footprint that are } \\
\text { relevant for its } \\
\text { supply chain? } \\
\text { (eg, commodities } \\
\text { such as cocoa, } \\
\text { coffee or sugar)? }\end{array}$ & Yes/No & $\begin{array}{l}\text { Yes. Kellogg's has } \\
\text { a Palm Oil } \\
\text { commitment and } \\
\text { has committed to } \\
\text { zero net- } \\
\text { deforestation for all } \\
\text { high risk } \\
\text { commodities } \\
\text { including sugar } \\
\text { cane. }\end{array}$ & Yes/No & Yes & $\begin{array}{l}\text { They have a policy } \\
\text { in place for Palm Oil } \\
\text { and a zero net } \\
\text { deforestation target } \\
\text { for all high risk } \\
\text { commodities. }\end{array}$ & $\begin{array}{l}\text { Responsib } \\
\text { le } \\
\text { Sourcing } \\
\text { (p.19) and } \\
\text { Kellogg } \\
\text { inputs } \\
\text { Excel } \\
\text { sheet }\end{array}$ \\
\hline \multicolumn{3}{|c|}{2.3 Measurement and metrics } & & $E / M / F$ & Meets & & \\
\hline
\end{tabular}




\begin{tabular}{|c|c|c|c|c|c|c|c|}
\hline & & & & & & & \\
\hline 25 & $\begin{array}{l}\text { What will the } \\
\text { process be for } \\
\text { regularly } \\
\text { measuring and } \\
\text { reporting on } \\
\text { GHGs in } \\
\text { operations, } \\
\text { supply chain, } \\
\text { and downstream } \\
\text { (scopes } 1,2,3) \text { ? } \\
\text { What tools or } \\
\text { models will be } \\
\text { used? }\end{array}$ & Detail & $\begin{array}{l}\text { Emissions are } \\
\text { reported to CDP. } \\
\text { Kellogg's used the } \\
\text { IPCC methodology } \\
\text { to set a benchmark } \\
\text { and then tested } \\
\text { that using two } \\
\text { third-party models - } \\
\text { the Sectoral } \\
\text { Decarbonization } \\
\text { Approach and the } \\
3 \% \text { Solution. These } \\
\text { models cover } \\
\text { Scopes } 1-3 \text { (with } \\
\text { some exclusions) } \\
\text { and the entire } \\
\text { global operations } \\
\text { of the company. In } \\
\text { addition, } 75 \% \text { of } \\
\text { company's direct } \\
\text { suppliers will report } \\
\text { to CDP by } 2020 \text {. }\end{array}$ & $E / M / F$ & Meets & $\begin{array}{l}\text { Both the process for } \\
\text { and the tools used } \\
\text { for measurement are } \\
\text { available. }\end{array}$ & $\begin{array}{l}\text { Climate } \\
\text { Policy } \\
\text { Context } \\
\text { and } \\
\text { Methodolo } \\
\text { gy (p.8) } \\
\text { and } \\
\text { Company } \\
\text { press } \\
\text { release, } \\
\text { "Kellogg } \\
\text { Company } \\
\text { Announce } \\
\text { s New..." }\end{array}$ \\
\hline 26 & $\begin{array}{l}\text { Will supplier-level } \\
\text { agricultural } \\
\text { emissions be } \\
\text { tracked directly } \\
\text { (vs. estimated } \\
\text { from total } \\
\text { ingredient yields } \\
\text { across all } \\
\text { suppliers of a } \\
\text { given } \\
\text { ingredient)? Will } \\
\text { the company } \\
\text { provide } \\
\text { tools/assistance } \\
\text { to suppliers to } \\
\text { track their } \\
\text { GHGs? }\end{array}$ & Detail & $\begin{array}{l}\text { Emissions will be } \\
\text { estimated from } \\
\text { crop yields. } \\
\text { Kellogg's will } \\
\text { supply the Cool } \\
\text { Farm Tool to } \\
\text { capture emissions } \\
\text { from rice } \\
\text { production, } \\
\text { nitrogen fertilizer } \\
\text { application, and } \\
\text { on-farm energy } \\
\text { use. }\end{array}$ & $\mathrm{E} / \mathrm{M} / \mathrm{F}$ & Meets & $\begin{array}{l}\text { The mix of actual } \\
\text { measurement vs. } \\
\text { estimated from } \\
\text { yields is unclear, but } \\
\text { the assumption is } \\
\text { the estimates are } \\
\text { large majority of the } \\
\text { numbers. The } \\
\text { company is } \\
\text { providing tools to } \\
\text { capture and estimate } \\
\text { to some suppliers as } \\
\text { well. }\end{array}$ & $\begin{array}{l}\text { Climate } \\
\text { Policy } \\
\text { Context } \\
\text { and } \\
\text { Methodolo } \\
\text { gy (p.9) }\end{array}$ \\
\hline 27 & $\begin{array}{l}\text { What Is the } \\
\text { process for } \\
\text { assessing and } \\
\text { reporting data on } \\
\text { carbon } \\
\text { reductions, } \\
\text { particularly } \\
\text { Scope } 3 \text { ? (eg, is } \\
\text { it certified by a } \\
\text { third-party for } \\
\text { data legitimacy?) }\end{array}$ & Detail & $\begin{array}{l}\text { Emissions are } \\
\text { reported to CDP } \\
\text { and } 75 \% \text { of } \\
\text { company's direct } \\
\text { suppliers will report } \\
\text { to CDP as well by } \\
2020 \text {. }\end{array}$ & $\mathrm{E} / \mathrm{M} / \mathrm{F}$ & Meets & $\begin{array}{l}\text { CDP is the third- } \\
\text { party for reporting } \\
\text { carbon data }\end{array}$ & \\
\hline \multicolumn{3}{|c|}{$\begin{array}{l}2.4 \text { Interim goals and target } \\
\text { adjustments/flexibility }\end{array}$} & & $E / M / F$ & Exceeds & & \\
\hline 28 & $\begin{array}{l}\text { Are there } \\
\text { targets in place } \\
\text { for interim } \\
\text { years? }\end{array}$ & Yes/No & $\begin{array}{l}\text { In addition to } 2020 \\
\text { targets set in } 2014 \text {, } \\
\text { "Kellogg will target } \\
\text { a Scope } 3 \mathrm{GHG} \\
\text { reduction of } 20 \% \\
\text { by } 2030 \text { " }\end{array}$ & Yes/No & Yes & $\begin{array}{l}2020 \text { targets were } \\
\text { already established } \\
\text { but have been } \\
\text { connected to these } \\
\text { longer term goals, } \\
\text { with } 2030 \text { goals } \\
\text { added as well }\end{array}$ & $\begin{array}{l}\text { Climate } \\
\text { Policy } \\
\text { Context } \\
\text { and } \\
\text { Methodolo } \\
\text { gy (p.8) }\end{array}$ \\
\hline 29 & $\begin{array}{l}\text { What are the } \\
\text { interim targets } \\
\text { and for which } \\
\text { parts of the } \\
\text { value chain? }\end{array}$ & Detail & $\begin{array}{l}\text { In addition to } 2020 \\
\text { targets set in } 2014 \text {, } \\
\text { "Kellogg will target } \\
\text { a Scope } 3 \mathrm{GHG} \\
\text { reduction of } 20 \% \\
\text { by } 2030 \text { " } \\
\end{array}$ & $\mathrm{E} / \mathrm{M} / \mathrm{F}$ & Meets & $\begin{array}{l}15 \% \text { normalized } \\
\text { reduction in Scope } 1 \\
\text { and } 2 \text { and } 20 \% \text { in } \\
\text { scope } 3 \text { (absolute) } \\
\text { by } 2030 .\end{array}$ & $\begin{array}{l}\text { Climate } \\
\text { Policy } \\
\text { Context } \\
\text { and } \\
\text { Methodolo } \\
\text { gy (p.8) } \\
\end{array}$ \\
\hline
\end{tabular}




\begin{tabular}{|c|c|c|c|c|c|c|c|}
\hline 30 & $\begin{array}{l}\text { How will the } \\
\text { company } \\
\text { incorporate the } \\
\text { evolving } \\
\text { science on } \\
\text { climate } \\
\text { change? }\end{array}$ & Detail & $\begin{array}{l}\text { "Kellogg's looks } \\
\text { forward to the } \\
\text { Sector } \\
\text { Decarbonization } \\
\text { Tool's final version } \\
\text { and working with } \\
\text { industry partners } \\
\text { and NGOs to } \\
\text { develop the } \\
\text { "Agriculture" } \\
\text { sector...targets for } \\
\text { Scope 3" }\end{array}$ & $\mathrm{E} / \mathrm{M} / \mathrm{F}$ & Exceeds & $\begin{array}{l}\text { The company has } \\
\text { stated clearly it will } \\
\text { work with industry } \\
\text { and NGOs on } \\
\text { science-based } \\
\text { targets for } \\
\text { agriculture explicitly }\end{array}$ & $\begin{array}{l}\text { Climate } \\
\text { Policy } \\
\text { Context } \\
\text { and } \\
\text { Methodolo } \\
\text { gy (p.6) }\end{array}$ \\
\hline 31 & $\begin{array}{l}\text { Is there a } \\
\text { process in } \\
\text { place to re-set } \\
\text { or re-establish } \\
\text { the goals before } \\
\text { the target year } \\
\text { if necessary? }\end{array}$ & Detail & $\begin{array}{l}\text { "Kellogg } \\
\text { will...reevaluate } \\
\text { the targets and the } \\
\text { tools, technologies } \\
\text { and sciences that } \\
\text { deliver them every } \\
5 \text { years at a } \\
\text { minimum, as well } \\
\text { as a reevaluation } \\
\text { and re- } \\
\text { establishment of } \\
\text { the targets..." }\end{array}$ & $E / M / F$ & Exceeds & $\begin{array}{l}\text { The company has a } \\
\text { clear statement of } \\
\text { intent to revisit goals } \\
\text { and science at least } \\
\text { within } 5 \text { years, if not } \\
\text { earlier }\end{array}$ & $\begin{array}{l}\text { Climate } \\
\text { Policy } \\
\text { Context } \\
\text { and } \\
\text { Methodolo } \\
\text { gy (p.6) }\end{array}$ \\
\hline \multicolumn{3}{|c|}{$\begin{array}{l}2.5 \text { Transparency and } \\
\text { communications }\end{array}$} & & $E / M / F$ & Meets & & \\
\hline 32 & $\begin{array}{l}\text { Is the information } \\
\text { on GHG reduction } \\
\text { targets and plans } \\
\text { available publicly } \\
\text { in a transparent } \\
\text { and accessible } \\
\text { manner? }\end{array}$ & Detail & $\begin{array}{l}\text { Yes, they file with } \\
\text { the CDP and this } \\
\text { report is publicly } \\
\text { available. }\end{array}$ & $\mathrm{E} / \mathrm{M} / \mathrm{F}$ & Meets & $\begin{array}{l}\text { CDP is considered } \\
\text { publicly available } \\
\text { (you have to } \\
\text { register, for free, to } \\
\text { access the report) }\end{array}$ & $\begin{array}{l}\text { Corporate } \\
\text { Responsib } \\
\text { ility Report } \\
\text { (p.62) }\end{array}$ \\
\hline 33 & $\begin{array}{l}\text { How will updates } \\
\text { on implementation } \\
\text { progress be } \\
\text { shared? How } \\
\text { frequently? }\end{array}$ & Detail & $\begin{array}{l}\text { "Kellogg will report } \\
\text { our progress } \\
\text { annually" }\end{array}$ & $\mathrm{E} / \mathrm{M} / \mathrm{F}$ & Meets & $\begin{array}{l}\text { Annual CDP Supply } \\
\text { Chain reporting } \\
\text { meets the } \\
\text { requirement }\end{array}$ & $\begin{array}{l}\text { Climate } \\
\text { Policy } \\
\text { Context } \\
\text { and } \\
\text { Methodolo } \\
\text { gy (p.6) }\end{array}$ \\
\hline
\end{tabular}




\section{APPENDIX B - INFORMATION ON THE AUTHORS}

Andrew Winston, Founder of Winston Eco-Strategies, is a globally recognized expert on how companies can navigate and profit from humanity's biggest challenges. His views on strategy have been sought after by many of the world's leading companies, including Boeing, Coca-Cola, HP, J\&J, Kimberly-Clark, PepsiCo, PwC, Unilever, and Walmart. Andrew's latest book, The Big Pivot was selected as one of the "Best Business Books" by Strategy+Business magazine. His first book, Green to Gold, was the top-selling green business title of the last decade and was included in Inc. Magazine's all-time list of 30 books that every manager should own. Andrew's speeches around the world, including a TED talk, provide a practical and optimistic roadmap to help leaders build resilient, thriving companies and communities in a volatile world. Andrew received degrees in economics, business, and environmental management from Princeton, Columbia, and Yale.

Jeff Gowdy is a well-known thought leader \& practitioner in sustainability and CSR, particularly in the arena of goal setting and reporting. He serves on the Technical Advisory Group for the CDP Science Based Targets project. Mr. Gowdy has served on hundreds of sustainability projects since 2002 for some of the world's largest companies, including 13 of the Fortune 1000 . Mr. Gowdy teaches in the Strategy \& Economics concentration at the Owen Graduate School of Management at Vanderbilt University and in the Executive Development Institute at Owen. Mr. Gowdy earned a Bachelor of Science degree in Systems Engineering from the University of Virginia and an MBA in Strategy \& Environmental Management from Vanderbilt University. He graduated with Honors from both programs. 